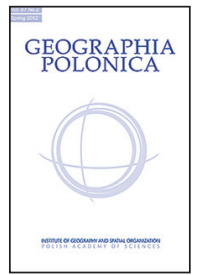

\title{
TIMBERLINE IN THE CARPATHIANS: AN OVERVIEW
}

\section{Barbara Czajka $\bullet$ Adam Łajczak ${ }^{2} \cdot$ Ryszard J. Kaczka ${ }^{1} \bullet$ Paweł Nicia ${ }^{3}$}

${ }^{1}$ Faculty of Earth Sciences

University of Silesia in Katowice

Będzińska 60, 41-200 Sosnowiec: Poland

e-mails: barczajka@wp.pl・ryszard.kaczka@us.edu.pl

${ }^{2}$ Institute of Geography

Pedagogical University of Krakow

Podchorążych 2, 30-084 Krakow: Poland

e-mail: alajczak@o2.pl

\author{
${ }^{3}$ Department of Soil Science and Soil Protection \\ University of Agriculture in Krakow \\ Mickiewicza 21, 31-120 Krakow: Poland \\ e-mail: rrnicia@cyf-kr.edu.pl
}

\begin{abstract}
In nature, division lines are delineated where multiple important environmental features change. These division lines may be singled out at the intersection of two geosystems (Balon 2000) where the functional uniformity of the geosystems located on both sides are preserved (Forman \& Gordon 1986; Cadenasso et al. 2003). A significant environmental boundary is the upper forest boundary (timberline), which separates different vegetation zones: (1) forest from non-forest (Piękoś-Mirkowa \& Mirek 1996); climatic zones (2) cool from very cool (Hess 1965); geoecological zones (3) periglacial from temperate forest system (Kotarba 1996). A timberline is a sensitive ecosystem therefore is a good indicator of changes occurring in the environment. There are, however, multiple elements which affect the timberline. This ecotone has also been widely analysed in local, regional, and even monographic studies of numerous massifs. It is necessary to present and organise the great amount of information in order to aid research on the timberline in the Carpathians.
\end{abstract}

\section{Key words}

boundaries in the mountain environment - timberline Carpathians

\section{The notion of boundaries in the geographical environment}

The question of boundaries appears in every study involving a spatial dimension of research (German 2000). Based on their origin, three types of boundaries can be distinguished: natural, anthropogenic, and agreed (Armand 1980). In nature, the division lines may be singled out at the intersection of two geosystems, where multiple important environmental features change (Balon 2000). The functional uniformity of the geosystems located on both sides is then preserved (Forman \& Gordon 1986; 
Cadenasso et al. 2003). Both biotic and abiotic as well as natural and anthropogenic factors affect the shape of the boundary. Natural boundaries are not usually sharp and have a transitional zone, called an ecotone. Elements from both areas occur in an ecotone, organisms from adjacent biocoenoses coexist, which leads to an increase in biodiversity (Allen \& Starr 1982; di Castri et al. 1988; Hansen \& di Castri 1992). The bigger the difference between the adjacent environments, the narrower the ecotone zone. The features of an ecotone are determined by time, development, and function: permeability, durability, and flexibility (Hansen \& di Castri 1992). Plants and animals achieving their environmental limit are exposed to tension and environmental stress. For that reason, an ecotone constitutes a good bioindicator of various changes occurring within the ecotone's range (Gosz \& Sharpe 1989).

A timberline is a good indicator of changes occurring in the environment. There are, however, multiple elements which affect a timberline. This ecotone has also been widely analysed in local, regional, and even monographic studies of numerous massifs. It was necessary to present and organise below, the great amount of available information for the purpose of researching the timberline in the Carpathians.

\section{The notion of timberline}

Several boundaries can be distinguished in a high mountain environment (Troll 1972, 1988; Price 1981). Usually there is a division into layers, when climate and other environmental components change together with the above sea level altitude. Outermost boundaries have different origins. The abiotic boundary of eternal snow, above which mountain glaciers may appear, is located the highest (Paterson 1994). Whereas in dry climates, the drought-caused timberline (lower timberline, dry timberline) is located in the mountain foothills. In the Carpathians, where the climate is humid, this boundary does not occur, but centuries of human activity resulted in the formation of an agricultural and forest anthropogenic boundary (Adamczyk et al. 1980; Sarmiento 2002; Kozak 2005).

A significant environmental boundary is the upper forest boundary (timberline), which separates different vegetation zones. These zones are: (1) forest from non-forest (Piękoś-Mirkowa \& Mirek 1996); climatic zones (2) cool from very cool (Hess 1965); geoecological zones (3) periglacial from temperate forest system (Kotarba \& Starkel 1972; Kotarba 1996). The adjective 'alpine' was added to the boundaries occurring in high-mountain systems and this word is also used nowadays (Brockmann-Jerosch 1919).

Scientific research articles provide multiple definitions of the upper forest boundary. These definitions have been modified with time. The differentiation between an ideal and empirical definition of the forest boundary was made as early as the beginning of 20th century (Fries 1913). However, even nowadays, numerous discussions are held on the definitions and their terminological differences. Although the available information on this subject has grown considerably since the 1990s, the Timoney's remark has maintained its accuracy: "(...) the tree line and other subarctic-arctic boundaries have been defined more often than they have been mapped" (Timoney et al. 1992).

The most common definition is the one of a potential/ hypothetical/ generalised upper forest boundary ('treeline') (TL) (Imhof 1900; Marek 1910; Fries 1913; Sokołowski 1928; Plesník 1971; Troll 1972). This would be the line connecting the uppermost patches of dense forest, which corresponds to the course of climatic upper forest boundary (Fig. 1). Heat deficiency is the global factor which determines the treeline existence (Daubenmire 1954; Hess 1965; Walter \& Medina 1969; Holtmeier 1974).

In reality, a potential treeline is affected by various elements, and therefore, a lot of research is focused on the actual course of a timberline (TE), called by Fries (1913) an empirical timberline (eTE). The term was changed into an empirical upper timberline 


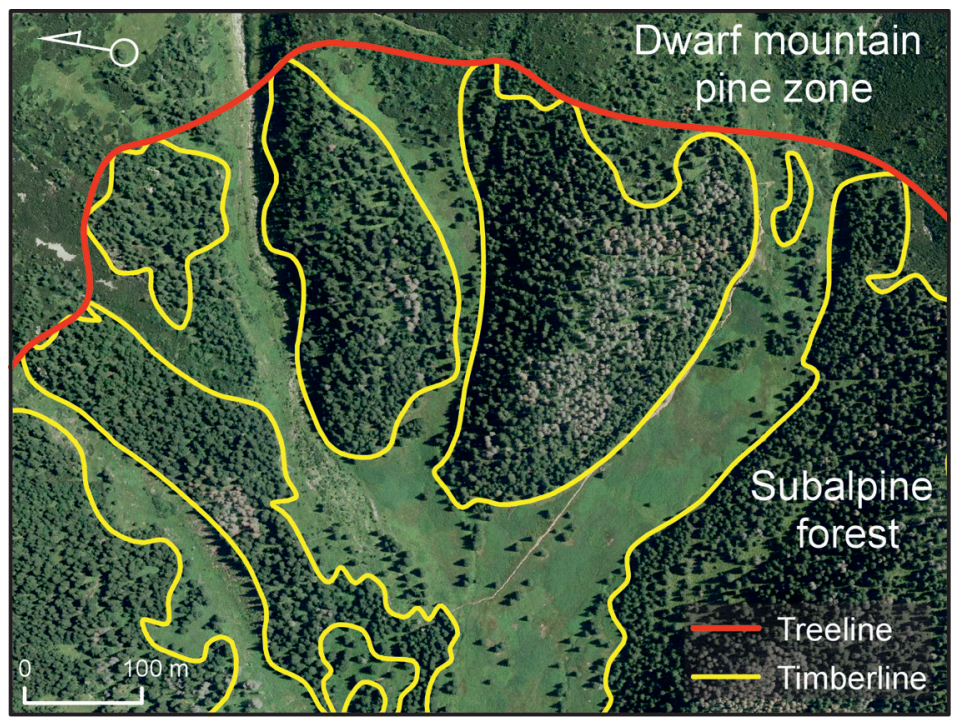

Figure 1. Spatial differences between treeline and timberline delineation

by Sokołowski (1928) for the purpose of the research carried out in the Tatras. An empirical timberline refers to the line connecting the highest locations of a dense forest and this line reflects the impact of all natural and artificial factors (Fig. 1). It is also called a biological timberline (Hustich 1953). Definitions of a timberline in English correspond to a dense forest boundary, but there are multiple variations of this term.

The large number of these terms, their interchangeability and misinterpretation result from various methodological criteria but also their application to the tree species range zones at different latitudes and in different climates (Troll 1973a,b). Moreover, the scale of the analysed areas is quite varied. On the one hand, there are studies on very small mountain areas like the Babia Góra Massif (Czajka et al. 2015a) or single valleys (Jodłowski 2007), which call for applying methodologies which emphasise the details and nuances of the investigated subject $(1: 10,000$ or 1:5,000 scale mapping). On the other hand, when similar issues are examined for the extended mountain ranges, e.g. entire Alps (Brockmann-Jerosch 1919) or Carpathians
(Weisberg et al. 2013) the results must be presented in the form of synthetic characteristics.

Numerous studies have been devoted to differentiating between a dense forest and a non-forest area. Such a differentiation is necessary to map out a linear spatial division between the dense forest and non-forest area. This division would be the empirical timberline. Three main criteria must be taken into account: the height of the trees, the crown cover/canopy cover/forest density, and the forested area. The fourth criterion is a secondary one - tree species (Tab. 1). According to many authors, trees growing on the forest side of the eTE should reach a height of 4-5 m (Schröter 1926), and up to $8 \mathrm{~m}$ (Sokołowski 1928; Vincent 1933; Zientarski 1985) or even $12 \mathrm{~m}$ for a beech timberline (Kucharzyk 2006). Minimum crown cover (that is how and to what extent tree crowns fill in the space of a tree stand, after Szymański 2000) was determined as: low ( $\geq 0.4)$ (Fekete \& Blattny 1913-1914) or medium (>0.5) (Plesník 1971), while in the case of beech forests - very dense (Kucharzyk 2006). According to Aas (1964) and Mork (1968), a forest can be called dense when the average distance between trees does not 
Table 1. The criteria used for determining an empirical timberline in Europe according to different authors

\begin{tabular}{|c|c|c|c|c|c|c|c|}
\hline Author & Location & Species & $\begin{array}{l}\text { Altitude } \\
\text { [m a.s.l.] }\end{array}$ & $\begin{array}{c}\text { Minimal height } \\
\text { of trees [m] }\end{array}$ & $\begin{array}{c}\text { Extent of forest } \\
\text { density }\end{array}$ & $\begin{array}{l}\text { Area } \\
{\left[\mathrm{m}^{2}\right]}\end{array}$ & Others \\
\hline $\begin{array}{l}\text { Fekete \& Blattny } \\
(1913-1914)\end{array}$ & $\begin{array}{l}\text { Mountains of the former } \\
\text { Austro - Hungarian } \\
\text { Empire }\end{array}$ & Spruce & $\sim 2000$ & 8 & low density $\sim 0.4$ & Not specified & $\begin{array}{l}\text { Distinguished between the 'tim- } \\
\text { berline' and the 'treeline'. Not } \\
\text { specifying whether they meant } \\
\text { empirical boundaries }\end{array}$ \\
\hline $\begin{array}{l}\text { Brockmann- } \\
\text {-Jerosch (1919) }\end{array}$ & Central Swiss Alps & $\begin{array}{l}\text { Spruce, Larch, } \\
\text { Swiss pine }\end{array}$ & 2250 & 5 & Not specified & Not specified & $\begin{array}{l}\text { Introduced the term alpine } \\
\text { timberline }\end{array}$ \\
\hline Däniker (1923) & Alps & $\begin{array}{l}\text { Spruce, Larch, } \\
\text { Swiss pine }\end{array}$ & $\sim 2200$ & * & Not specified & Not specified & \\
\hline Schröter (1926) & Alps & $\begin{array}{l}\text { Spruce, Larch, } \\
\text { Swiss pine }\end{array}$ & $\sim 2200$ & $4-5$ & Not specified & Not specified & $\begin{array}{l}\text { Elaborated on the definition } \\
\text { of struggle belt (kampfzone) }\end{array}$ \\
\hline Sokołowski (1928) & Tatra Mts. & $\begin{array}{l}\text { Spruce, Larch, } \\
\text { Swiss pine }\end{array}$ & $\sim 1700$ & 8 & low density & Not specified & \\
\hline $\begin{array}{l}\text { Vincent }(1933, \\
\text { 1938) after Guzik } \\
(2008)\end{array}$ & Vysoké Tatry Mts. & $\begin{array}{l}\text { Spruce, Larch, } \\
\text { Swiss pine }\end{array}$ & $\sim 1700$ & 8 & $\begin{array}{l}\text { Forest cover } \\
\quad>0.5\end{array}$ & $>10,000$ & \\
\hline $\begin{array}{l}\text { Svoboda (1934) } \\
\text { after Guzik (2008) }\end{array}$ & Tatra Mts. & $\begin{array}{l}\text { Spruce, Larch, } \\
\text { Swiss pine }\end{array}$ & $\sim 1700$ & 8 & Not specified & Not specified & \\
\hline Środoń (1948) & $\begin{array}{l}\text { Chornohora Mts. and } \\
\text { Chyvchyns'ki hory Mts. }\end{array}$ & $\begin{array}{l}\text { Beech (a), Spruce } \\
\text { and Swiss pine (b) }\end{array}$ & $\begin{array}{l}\sim 1200(a) \\
\sim 1650(b)\end{array}$ & 8 & Not specified & Not specified & \\
\hline $\begin{array}{l}\text { Rubner (1953) after } \\
\text { Holtmeier (2009) }\end{array}$ & Tatra Mts. & Spruce, Swiss pine & & $6-8$ & Low density & Not specified & \\
\hline $\begin{array}{l}\text { Somora (1958, } \\
\text { 1969) }\end{array}$ & Slovakian Tatra Mts. & $\begin{array}{l}\text { Spruce, Swiss } \\
\text { pine, Larch }\end{array}$ & $\sim 1700$ & 8 & $\begin{array}{l}\text { Low density } \\
\quad 0.4\end{array}$ & Not specified & Promoted the name Waldgrenze \\
\hline $\begin{array}{l}\text { Jeník \& Lokvenc } \\
\text { (1962) }\end{array}$ & Krkonoše Mts. & Spruce, Beech & $\sim 1300$ & 5 & $\begin{array}{l}\text { Forest cover } \\
\quad>0.5\end{array}$ & $>100$ & $\begin{array}{l}\text { Proposed the criterion that the } \\
\text { distance of isolated enclaves } \\
\text { from a timberline does not } \\
\text { exceed } 100 \mathrm{~m}\end{array}$ \\
\hline
\end{tabular}




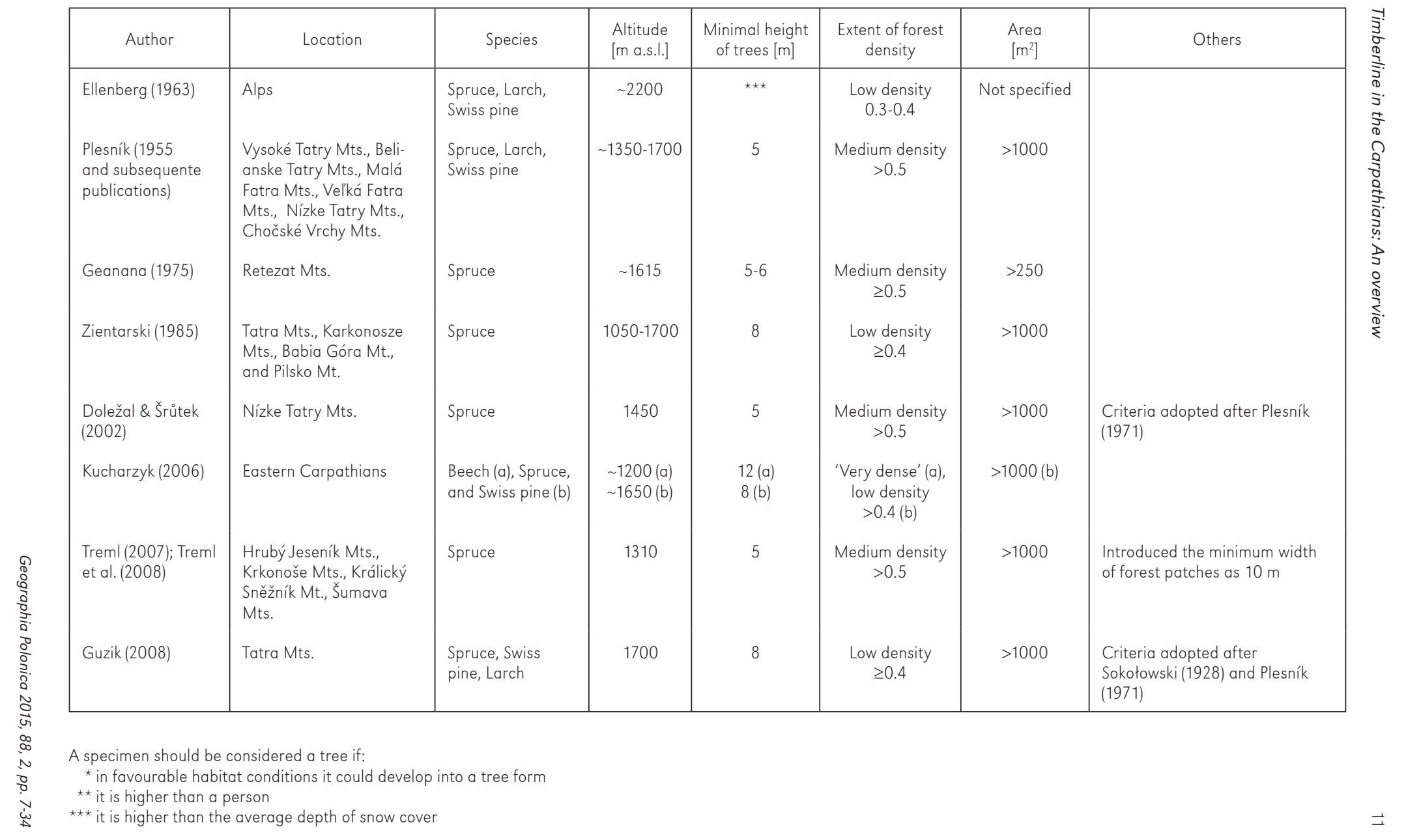


exceed $30 \mathrm{~m}$. The biggest differences concern the minimum forest cover to be called a forest: from 1 are (Jeník \& Lokvenc 1962) to 1 hectare (Vincent 1933). The discrepancies are considerable and authors often fail to provide the adopted criteria and to justify their choices. For these reasons, the comparison and analysis of results is made difficult.

The secondary criterion to be taken into account is the tree species dominating in the forest above the eTE. During his research in the Tatra Mountains, Guzik (2008) excluded the community of Athyrio-Sorbetum, forests with mountain ash (Sorbus aucuparia L.) from this ecotone. Such an assumption can be applied only to the areas where the uppermost forest sections are clearly dominated by coniferous species and to areas which do not involve mountain regions where there is a beech timberline (e.g. Western Bieszczady (522.12), Połonyns'ki hory (522.2) and the Cernei Mountains in the Godeanu Mountains (531.33 according to the regionalisation by Kondracki 1978).

The character of a dense forest boundary is also affected by the shape and type of the ecotone above it. Above the eTE, a forest thins out, while trees become crippled to increase their chances of survival (Paulsen et al. 2000; Körner 2012a). The upper boundary of trees (tree species line) can be distinguished (Fig. 2). The very notion of a 'tree' is also defined differently and its height is considered the main criterion. As Holtmeier (2009) claimed, according to numerous authors these are specimens with a height of from 1 to $8 \mathrm{~m}$, depending on the species. Tree species reaching the uppermost areas remain crippled. The uppermost areas are the upper boundary of shrub-like trees (krummholz-line). Depending on the mountain region, krummholz-line term refers both, to plants whose growth course is determined by habitat conditions (e.g. winter forms) (Norton \& Schonenberger 1984) and those whose growth course is conditioned genetically (e.g. Pinus mugo in Carpathians) (Holtmeier 1981; Grace 1989). The area between a dense forest and the upper boundary of trees is defined as the struggle zone (Kampfzone) (Däniker 1923). The interface of a varied width between the forest layer and the dwarf mountain pine layer is called a timberline ecotone (Troll 1972; Tranquillini 1979; Slatyer \& Noble 1992; Holtimeier 2009).

\section{Timberline fluctuations during the Holocene}

Depending on the climatic conditions, in the Holocene a timberline went through several regressive and progressive phases. Palynological research from the Alps (Wick \& Tinner 1997; Carcaillet \& Brun 2000; Van der Knaap et al. 2000; Wick et al. 2003) confirms that the timberline reached its uppermost location in the Mid- to Late Holocene $(6,000-3,500$ BP

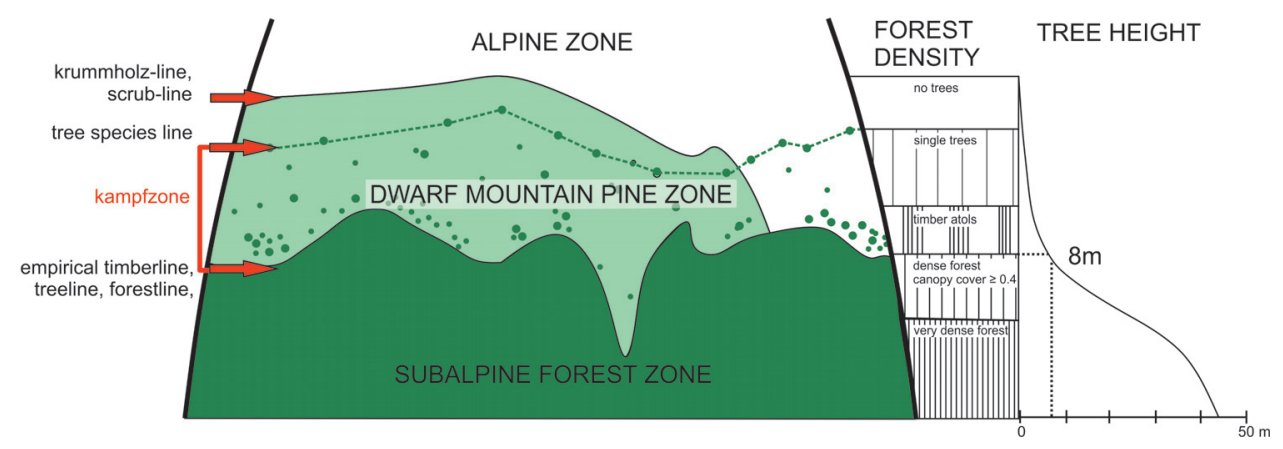

Figure 2. The transition-area model in the mountain environment of a temperate climate together with the criteria for timberline delineation

Source: based on Sokołowski 1928; Holtmeier 2009; Körner 2012b 
in the Northern Alps, 8,000 - 5,000 BP in the Central and Southern Alps). While in the Western Carpathians, the Tatras (Obidowicz 1996), and the Żywiec Beskids (Obidowicz 2003, 2004) the timberline reached its highest range (in the Tatra Mountains up to the height of $1700 \mathrm{~m}$ ) later, in the Older Subboreal period (3,000-2,000 BP). From that time, the range of the timberline lowered until the end of the 'Little Ice Age' ( 1850), while since the Bronze Age ( 3,400 BP), the structure and location of the timberline have been strongly affected by human activity. The natural, climate-change-related fluctuations of the timberline's range in the Holocene did not exceed 200 - 300 m (Carcaillet \& Brun 2000; Wick et al. 2003). In the last century of intensive human interference, changes in the location of the timberline have been observed in many mountain massifs in the world (Wieser \& Tausz 2007). Nowadays, in the age of global climate warming, another phase of a forest ascending higher altitudes is expected. However, the scale of these changes may be intensified or, on the contrary, slowed down and hindered, due to the centuries-old human impact on the high-mountain environment.

The stability of a geosystem and a possible disturbance of the balance depend on two variables:

- the type, spreading potential, intensity, and frequency of the occurrence of the stimulus affecting the geosystem,

- the sensitivity and susceptibility of the natural environment, i.e. its inclination to succumb to such stimuli - its internal features (Turner 1988; Kistowski 2000; Balon 2001). In the natural or semi-natural environment, the stability of the environment decreases with the increase of the altitude a.s.l. and slope inclination, but determining such a simple relation in the human-disturbed environment is impossible (Balon 2007).

The system's stability is understood in two ways:

- as its durability in the unchanged environmental conditions, but also,

- as its ability to return to the state resembling the original one after the exposure to the disturbing external factors has finished (Richling \& Solon 1996; Balon 2007).

The durability in the unchanged environmental conditions can be narrowed to a particular time span. Then, the system's permanence must be dealt with, which is the best expression for nature systems (Malinowski et al. 2004). Orographic, soil and anthropogenic barriers, and most of all, a climatic barrier, constitute major elements stabilising a timberline location (Hess 1965).

\section{Natural environmental factors shaping the course of a timberline in the Northern Hemisphere}

In the existing studies on timberlines, most attention is paid to the direct cause of vegetation boundaries in the mountains, i.e. the reaction to stress factors: abiotic and biotic ones (research in the Alps: Brockmann-Jerosch 1919; Troll 1973a; Körner 1998).

There are numerous review studies on the timberline (Grace 1989; Körner 1998; Jobbágy \& Jackson 2000; Holtmeier \& Broll 2007; Wieser \& Tausz 2007; Holmeier 2009; Körner 2012 b). These studies focus on the importance of the climate as a restricting factor (in a timberline ecotone) and preventing the growth of trees (above the timberline). According to research, the potential location of a timberline corresponds to the course of:

- an annual isotherm of $2^{\circ} \mathrm{C}$ (the Tatras: Hess 1965);

- a vegetation period isotherm of $5.5^{\circ} \mathrm{C}$ - $7.5^{\circ} \mathrm{C}$ (the Venezuelan Andes: Walter \& Medina 1969; the Alps: Hoch et al. 2002; worldwide timberline: Körner 2012b);

- a $10^{\circ} \mathrm{C}$ isotherm of the warmest month (mountain regions in North America: Daubenmire 1954; Fennoscandia and the Alps: Holtmeier 1974).

The average temperature of the coldest month affects the type of vegetation adjacent to a timberline (worldwide timberline: Jobbágy \& Jackson 2000). The microclimate to which a given plant is exposed, for example, soil temperature exposure, is also important (worldwide timberline: Körner 
\& Paulsen 2004). It has been pointed out that in humid mountain regions, the average soil temperature is significant. The minimum average soil temperature value during the vegetation period should reach $6.7^{\circ} \mathrm{C} \pm$ $0.8^{\circ} \mathrm{C}$ (worldwide timberline: Hoch \& Körner 2003). Körner (1998), and others, think every tree species has a minimum temperature below which growth processes are slowed down or entirely stopped. This hypothesis was confirmed in the Italian Alps by Rossi et al. (2007). They determined the xylem activity threshold, when the average daily air temperature amounts to $5.6^{\circ} \mathrm{C}-8.5^{\circ} \mathrm{C}$, and the average trunk temperature is $7.2^{\circ} \mathrm{C}$ $-9.0^{\circ} \mathrm{C}$ (depending on the tree species). It has also been found, that the occurrence of very low temperatures, which do not pose any threat to a timberline as such, may damage plants directly and contribute to growth distortions resulting from partial damage (the Alps: Tranquillini 1979; Larcher 1985). Additionally, the role of solar radiation rises with altitude to balance the lower and lower air temperature (Wilczyński 2004).

The altitude of the timberline in the Northern Hemisphere is inversely proportional to the latitude at which it is located (Troll 1973b; Wardle 1974; Arno 1984; Körner 1998; Holtmeier 2009). This relationship is connected with the evident mechanism of the increasing warmth deficiency going from the Equator to the Poles (Cogbill \& White 1991; Jobbágy \& Jackson 2000). The relationship is not a linear interdependence. In circumpolar regions the location of a timberline drops drastically in the Southern Hemisphere and occurs 1000-1500m lower than in the Northern Hemisphere (Körner 1998). Research proves that continental climate provides favourable conditions for a forest to be located at higher altitudes (Siberia and the Himalayas: Malyshev 1993; Fang et al. 1996; Malyshev \& Nimis 1997).

In mountains with moderate humid climates, air temperature, but also the sum of precipitation and the humidity of the environment play an important role in the position and condition of the timberline ecotone (Ślaski Beskids: Feliksik \& Wilczyński 2000). High precipitation during the summer has a negative effect on the condition of trees because cloudiness and rainfall lower air temperature (Wilczyński \& Gołąb 2001).

Such factors as the occurrence of snow and wind activity are closely related to the climate. The thickness and duration of snow cover affect a timberline to a considerable extent. A prolonged period of snow cover shortens the vegetation period and reduces plant resistance. Large amounts of wet, heavy snow result in the creation of snow caps, which break branches or even entire trees (Grace 1977). On the other hand, snow cover can also protect plants against the destructive activity of strong wind, physiological draught and parasitic fungi (the Alps: Däniker 1923; Schröter 1926; Donaubaur 1963; Holtmeier 1974; Tranquillini 1979; Aulitzky \& Turner 1982; Larcher 1985). Wind has an impact on evapotranspiration and the reduction of snow cover (Larcher 1985; Havranek 1993). Wind can also result in the formation of specific flagged krummholz of tree crowns (Holtmeier 1996). Cold winds increase the penetration of low temperatures and frost into the soil, which causes physiological drought (worldwide boreal forest: Bonan 1992). Weakened stands in valley narrowings are most susceptible to the destructive impact of wind activity (the Tatras: Kotarba 1970). However, wind helps transport seeds upslope - anemochory (Siberia: Shiyatov 1966; Havranek 1993).

Apart from the most frequently discussed climate-related factors, other environmental components which influence the location and nature of a timberline have been determined. There are numerous classifications which can be generally divided into groups according to: physiological factors, landform features, lithology, morphogenetic processes, biotic factors, and anthropogenic influence (the Polish Carpathians: Jodłowski 2007).

Physiological factors are strongly related to climatic and weather conditions. They include physiological drought, i.e. tree 
dehydration caused by extracellular freezing of water (Research in the Alps: Larcher 1985; Tranquillini 1976, 1979, 1982; the Sierra Nevada Mountains: Sowell et al. 1982; New Zealand's and Australian Mountains: Sakai \& Larcher 1987; the Alps: Havranek \& Tranquillini 1995). In the Western Carpathians the problem becomes most serious in spring at sunny southern slopes, where the soil is still frozen but strong radiation stimulates the trees to grow (Wilczyński 2004).

Interspecies competition for access to light, water, and mineral elements constitutes a biotic element (Tatra Mountains: Sokołowski 1928). With a rise in altitude, it becomes less likely for a sapling to take root successfully above a timberline. Problems with rooting may be affected by the lack of vital diaspore (New Zealand's Mountains: Norton \& Schonenberger 1984; Scotland: Grace \& Morton 1990).

It is thought that a zero production of organic matter caused by an unfavourable climate, is one of the elements which control forest location (the Alps: Boysen-Jensen 1949; Stevens \& Fox 1991; Slatyer \& Noble 1992; Glacier National Park, USA: Cairns 1998; Cairns \& Malanson 1998). To date, though, no further research has found a connection and confirmed this hypothesis (New Zealand's Mountains: Wardle 1971; North America Mountains: Ives 1978; Arno 1984; Holtmeier 2009).

Mycorrhizal fungi decompose organic matter and enable trees to absorb microelements (mostly phosphorus, nitrogen, but also zinc and copper, as well as the plant hormones: auxin, gibberelin and cytokonin). These fungi play an important role in the circulation of nutrients in the timberline ecotone soils. Fungi are thought to act as a buffer and an emergency container of nutrients (Read \& Perez-Moreno 2003). Mycorrhiza helps trees to resist harsh climatic conditions and helps trees advance to higher altitudes (Read 1998). All trees growing in the timberline ecotone are mycorrhizal (the Canadian Mountains: Kernaghan \& Currah 1998; Kernaghan 2001; worldwide review: Haselwandter 2007). Mycorrhizal fungi help young saplings to take roots in a timberline (North American Mountains: Hasselquist et al. 2005). In the harsh high-mountain environment, cooperation between organisms is more important than interspecies competition (North American Mountains: Callaway 1998).

The altitudinal timberline location is highly dependent on landform features and topography. Research on this subject describes the mass-elevation effect (mountain-mass effect, massenerhebungseffekt, Merriam effect) (the Alps: Di Quervain 1904; Brockmann-Jerosch 1919; Tollner 1949) connected with the continental effect. The larger the massif is, the higher the plant and climatic zones are located. Additionally, the closer to the massif centre, the more intense the effect is. For example, in the central part of the Austrian Alps, the vegetation period is 80 days longer compared to the external ranges (Turner 1961). During his research on the snowline in the Alps, Di Quervain (1904) came to the conclusion that the snowline was located higher within the Alpine system (the Central Alps) than in the surrounding Eastern and Western Alps. For many years the mass-elevation effect was forgotten and disregarded in the studies on timberlines (Hermes 1955; Körner 1998; Jobbágy \& Jackson 2000).

Slope exposure and inclination constitute the main determinant in microclimate changes and, consequently, flora distribution (the Alps: Geiger 1961; the Tatras: Plesník 1971). The amount of radiation that reaches the surface depends on the landform features. The differences in the radiation amounts are reflected in: the soil and air temperature variations, the duration of snow cover, and soil humidity (the Alps: Barry \& Van Wie 1974; Larcher 1985; the Italian Alps: Turner 1993). It has also been observed that upper river-valley sections influence the timberline lowering. Such an influence is the so-called 'valley phenomenon' (Fries 1913). This phenomenon takes into account the combined effect of the activity of thermal (lower heating), orographic, and economic factors (the Tatras: Kotula 
1889-1890; Sokołowski 1928; Hess 1965). Diversified landform features, such as cliffs, rock walls or crags, constitute a barrier for forest development. On the other hand, these features act as protection from destructive human activity (the Polish Carpathians and the Fenoscandia: Balon 1995).

These factors and the type of substratum where particular plant habitats occur, have an indirect impact on the soil typology. The bedrock that soils originated from decide the soil typology.

Depending on the bedrock and its susceptibility to erosion processes, which occur in a time unit, soils of various soil profile depth and diverse physical and chemical features may be created (Dobrzański 1995). Considering these factors, soil can be considered one of the most complex elements of the natural environment which affect a timberline ecotone. Among the features which affect the course of a timberline ecotone are such soil parameters as: $\mathrm{pH}$, grain composition or sorption properties, as well as groundwater level and their ionic composition, which also influence the accumulation of organic matter ( $\mathrm{Ni}$ cia 2009; Heckman et al. 2009).

There is not much research into ecotone zone soils. The majority of the research which has been done concerns the Alps (Friedel 1967; Bednorz 2000). It was indicated that substratum built of quartzite rocks contributes to a timberline lowering. The biggest differences in the eTE course were observed when comparing carbonate and carbonate-free rocks (the Tatras: Sokołowski 1928; Myczkowski 1955a; Plesník 1956, 1967, 1971; the Alps: Arno 1984). These rocks are susceptible to erosion, and consequently, prone to the formation of soil cover. The thickness of soil cover in a timberline ecotone is also connected with the inclination of slopes and erosion processes occurring in the surface soil layer. Soils which appear on slopes with smaller inclines, where the intensity of erosion processes is lower, are characterised by thicker soil profiles. The surface organic and mineral layers, as well as the depth of the entire soil profile are thicker (Musielok et al. 2013).
The occurrence of violent geomorphological processes (snow and stone avalanches, rockfalls, debris flows, debris and mud flows, lahars) is related to the landform features. In a typical high-mountain environment, the initial avalanche zone and the debris flow failure zone start in the morphogenetic periglacial (cryonival) system. The avalanche activity has a direct or indirect influence on a temperate forest system (the Tatras: Kotarba \& Starkel 1972; Kotarba et al. 1987; Raczkowska 2007). The smaller the slope inclination and the farther the distance between the timberline and peaks, the smaller the range of timberline affected by these processes (Holtmeier 2009). The location and structure of a forest reflect the area's topography and landform features. A forest occupies convex landforms, while concave ones constitute the flow paths of, for example, avalanches. A forest reaches its uppermost location in the areas unaffected by avalanches - in small valleys of gentle slopes (Holtmeier 1974). A spruce (the most prevalent species in the timberline ecotone in the Carpathians) is a tree with an extensive but shallow root system, which makes it less resistant to morphogenetic processes. Trees growing on the edge of avalanche runout zones often suffer mechanical injuries. The overall condition of these trees is adversely affected by the injuries (Myczkowski 1955a; Stoffel et al. 2010). The content and structure of stands located within the range of avalanches alter diametrically. The bottom of the avalanche runout sector is dominated by species which are more flexible and more resistant to mechanical injuries and to a thick, long-lasting snow cover (Pinus mugo, Alnus Mill., Sorbus aucorparia, Salix L., Betula L.) (Canadian Mountains: Johnson 1987).

\section{The influence of anthropopressure on the timberline in the Carpathians}

People have affected and transformed their surroundings for over 5500 years. For the last 200-300 years the influence has intensified 
(worldwide studies: Goldewijk 2001). At present, there are only 280,000 hectares of natural or semi-natural forests of the upper wooded section left in the Carpathians (WWF 2001). In the high-mountain areas, human activity in the timberline has involved degradation of the environment through ore mining and metallurgy, sheep and cattle pasturing, and forest clearing for the production of charcoal. The outbreaks of secondary pest (e.g. spruce bark beetle), are a direct effect of the draining of natural resources and weakening of stands. Tourism has also had an increased impact on forests (Jodłowski 2007).

Environmental pollution and pollution-related damage to vegetation is an indirect result of human activity (Unsworth \& Fowler 1988). Pollution originally appeared with the rapid development of heavy industry in the middle of the 20th century in Central Europe. Sulphur oxides $\left(\mathrm{SO}_{4}\right.$ and $\left.\mathrm{SO}_{2}\right)$ and nitrogen compound emissions, and the release-related acid rains mostly affected the forests in the Sudetes located in the so-called 'black triangle' (Michaelis 1997; Danielewicz \& Zientarski 2004). The Western and Eastern Carpathians were less affected by air pollution and pollution-related, acid rains. Since the main emission sources were distant and located on the windward side, the increased pollution in these mountain areas was smaller and occurred at a slower pace (Muzika et al. 2004; Fleischer et al. 2005).

In the last 50 years, reserve or strict protection measures have been implemented in many Carpathian massifs. As a result, the ecological balance in the high-mountain environment is being restored and reforestation is proceeding. The Carpathian Convention is a framework agreement for establishing cooperation and comprehensive policy for the protection and sustainable development of the Carpathians, was started up in 2003. It contributed to the establishment of the Carpathian Network of Protected Areas (CNPA) in 2006. Currently, $18 \%$ of the Carpathian area is under protection. There are 285 protected areas, including 36 national parks (Fall 2007).

\section{Research on the timberline ecotone in the Carpathians}

The oldest scientific studies on a forest height range, date from over 200 years ago and concern the Alps (e.g. Hacquet 1779; Zschokke 1804; Sendtner 1854; Kerner 1864/1865 after Holtmeier 2009). Forest ranges in the Carpathians were mapped out in the second half of the 19th century (Janota 1866; Zapałowicz $1879,1889)$. Systematic research began with the studies of Imhof (1900), Marek (1910) and Brockmann-Jerosch (1919). Until the beginning of the 20th century, except for one study on the timberline in the Schwarzwald (Drude 1890 after Holtmeier 2009), the alpine regions were the only mountain regions studied in Europe. Since the 1920s, systematic and comprehensive research on timberlines has been conducted all over the continent. However, no other mountain region has as extensive a collection of scientific studies on this subject as the Alps.

The most important results about the timberline in the Carpathians have been collected in Table 2. The first study on the Carpathians by Fekete \& Blattny (1913-1914) is a monographic delineation of altitudinal ranges (maximum and average) of particular tree species and vegetation layers (for different exposures) in the former Austro-Hungarian Empire. This study contains tabular lists without detailed explanatory notes or descriptions of the research methodology.

The timberline in the Tatras (514.5) has been the centre of attention since the beginning of research in the Carpathians. The studies were initiated by the following researchers interested in the Tatras: Janota (1866) and Sokołowski (1928), Myczkowski (1955a, 1955b, 1964), Fabijanowski (1955), Zientarski (1985) as well as the Czech researchers and Slovakian researchers: Vincent (1933), Svoboda (1934), Somora (1958, 1969), and Plesník (1967, 1971, 1973). Recently, the empirical timberline in the Tatras was examined by Guzik (2008), while its dendrochronological condition was studied by Czajka (2010) and Kalafarski (2011), and the geomorphological condition was studied by Kotarba (1996). 
Table. 2. Summary of key results of the timberline research in the Carpathians (not including the research carried out in the massif of Babia Góra, which are described in a separate chapter)

\begin{tabular}{|c|c|c|}
\hline Author (year) & Study area & The most important results \\
\hline Janota (1866) & Tatra Mts. & Specifies the altitudinal ranges of individual species of trees, including Pinus cembra, Picea abies, and Pinus mugo. \\
\hline Zapałowicz $(1879,1889)$ & $\begin{array}{l}\text { Babia Góra Mt., Pokuts'ko- } \\
\text { Bukovins'kì Karpati Mts. }\end{array}$ & $\begin{array}{l}\text { He described the average altitude of the timberline (using a barometer) throughout the massif and the detailed } \\
\text { altitude of the timberline in a few important places. }\end{array}$ \\
\hline Fekete \& Blattny (1913-1914) & $\begin{array}{l}\text { Mountains of the former } \\
\text { Austro - Hungarian Empire }\end{array}$ & $\begin{array}{l}\text { A tabular summary of the max., mean, and min. altitudinal ranges of each species with the division based on } \\
\text { slope exposure. Distinguished timberline and treeline providing rules for their determination (Tab. 1). }\end{array}$ \\
\hline Sokołowski (1928) & Tatra Mts. & $\begin{array}{l}\text { Apart from specifying clear methodology for timberline marking, connected timberline occurrences with ecological } \\
\text { conditions - environmental factors and anthropogenic impact. Moreover, he observed the influence of mass-eleva- } \\
\text { tion effect and "valley phenomena" on a timberline. He established the definition of empirical upper timberline. }\end{array}$ \\
\hline Kubijowicz $(1926,1927)$ & $\begin{array}{l}\text { Eastern Beskids, Żywiec } \\
\text { Beskids }\end{array}$ & $\begin{array}{l}\text { History of the pasturing in the studied areas, together with quantitative information about cattle and sheep } \\
\text { grazing. Description of the beginning of the clearing above and below the TE. A brief mention of the impact } \\
\text { of grazing on the environment. }\end{array}$ \\
\hline Jakób (1937) & Gorgany Mts. & $\begin{array}{l}\text { A study on the impact of environmental factors on the timberline. The wind caused TE lowering. He drew atten- } \\
\text { tion to the need to protect the stone-pine forests which were heavily used. }\end{array}$ \\
\hline Środoń (1948) & $\begin{array}{l}\text { Chornohora Mts. and } \\
\text { Chyvchyns'Ki hory Mts. }\end{array}$ & $\begin{array}{l}\text { A study on the human impact on the formation of 'Poloninas' (clearings on top of the mountains ends with } \\
\text { beech timberline). Denies the claims that the beech timberline is natural. }\end{array}$ \\
\hline Somora $(1958,1969)$ & Slovakian Tatra Mts. & Altitudinal ranges of timberline in the Liptowskie Tatras with clear methodology (Tab. 1). \\
\hline $\begin{array}{l}\text { Myczkowski (1955a, 1955b, } \\
\text { 1956, 1962) }\end{array}$ & Polish Tatra Mts. & $\begin{array}{l}\text { Short popular-science articles describing the entire spectrum of the types of TE in the Tatras. A case study } \\
\text { in the Mała Koszysta massif (with emphasis on the effects of wind) and in Rybi Potok Valley (climate impact, } \\
\text { avalanches, and interspecific competition). }\end{array}$ \\
\hline $\begin{array}{l}\text { Plesník (1955, 1956, 1957, } \\
\text { 1958, 1966, 1967, 1971, } \\
1973,1978,2002)\end{array}$ & $\begin{array}{l}\text { Vysoké Tatry Mts., Belianske } \\
\text { Tatry Mts., Malá Fatra Mts., } \\
\text { Vel'ká Fatra Mts., Nízke Tatry } \\
\text { Mts., Chočské Vrchy Mts. }\end{array}$ & $\begin{array}{l}\text { A series of monographic studies on the functioning of the TE in the Slovak Carpathians. Described the most } \\
\text { important factors that modified the TE in all massifs; extensive use of current knowledge. }\end{array}$ \\
\hline Zarzycki (1963) & Western Bieszczady Mts. & $\begin{array}{l}\text { Research on the history of the creation of 'Poloninas'. Author concluded that TE in the Bieszczady is reduced by } \\
100-200 \mathrm{~m} \text { in relation to the natural state. }\end{array}$ \\
\hline $\begin{array}{l}\text { Geanana }(1972,1975,1991, \\
1996,2004)\end{array}$ & $\begin{array}{l}\text { Retezat Mts., Romanian } \\
\text { Carpathians }\end{array}$ & $\begin{array}{l}\text { Studied the effects of altitude, soil cover, and the mass-elevation effect of the location of the timberline in the } \\
\text { Romanian Carpathians, with particular emphasis on the Retezat Mts. }\end{array}$ \\
\hline Zientarski (1985) & $\begin{array}{l}\text { Tatra Mts., Karkonosze Mts., } \\
\text { Babia Góra Mt. and Pilsko Mt. }\end{array}$ & $\begin{array}{l}\text { Confirmed the influence on the course of the mass-elevation effect on the timberline, and studied the impact of } \\
\text { natural and artificial factors. }\end{array}$ \\
\hline
\end{tabular}




\begin{tabular}{|c|c|c|}
\hline Author (year) & Study area & The most important results \\
\hline Kotarba (1996) & Tatra Mts. & $\begin{array}{l}\text { Author separated geocomplexes in the alpine environment, which are extended versions of the climate zones, } \\
\text { containing geomorphological aspects. }\end{array}$ \\
\hline $\begin{array}{l}\text { Gubka (1996), } \\
\text { Gubka \& Pittner (2013) }\end{array}$ & Nízke Tatry Mts. & $\begin{array}{l}\text { Ecological considerations on the condition of spruces growing on the TE depending on the altitude and expo- } \\
\text { sure-case study. }\end{array}$ \\
\hline Kucbel (2001), Seben (2005) & Nízke Tatry Mts. & $\begin{array}{l}\text { Development of forest sciences for the best selection of quality spruce seedlings to artificial plantings around } \\
\text { the slopes threatened by avalanches. }\end{array}$ \\
\hline Doležal \& Šrůtek (2002) & Nízke Tatry Mts. & $\begin{array}{l}\text { The study of changes in the structure and composition of plant communities in conjunction with the soil and } \\
\text { snow along the altitude transect (including also the TE). The timberline altitude was set at } 1420-1510 \mathrm{~m} \text { a.s.l. } \\
\text { Altitude explains } 35 \% \text { of variation in the forest. }\end{array}$ \\
\hline $\begin{array}{l}\text { Kucharzyk (2006); } \\
\text { Kucharzyk \& Augustyn (2008); } \\
\text { Augustyn \& Kucharzyk (2012) }\end{array}$ & Eastern Carpathians & $\begin{array}{l}\text { Analysis of the TE changes in the Eastern Carpathians based on aerial photography and digitalisation of } \\
\text { cadastral maps and Josephine and Franciscan Metrics from XVII / XVIII. Over the past } 150 \text { years, the beech } \\
\text { timberline in the Western Bieszczady is practically stable (mean altitude increase } 10 \mathrm{~m} \text { ). Indicates differences } \\
\text { in the ecology (resistance and resilience) of beech and spruces, conditioning the different nature of the TE. }\end{array}$ \\
\hline Mihai et al. $(2006,2007)$ & Bucegi and lezerul Mts. & $\begin{array}{l}\text { Based on aerial photographs from } 1990 \text { and } 2000 \text { taken in Bucegi Mt. they observed regeneration of beech } \\
\text { forests and deforestation of mountain shrub pine caused by grazing. In turn, in the lezerul Mts. from } 1886 \text { to } \\
2002 \text {, they observed a timberline altitude increase, the replacement of coniferous forests by mixed forests, and } \\
\text { a natural regeneration of beech trees. }\end{array}$ \\
\hline Török-Oance et al. (2006) & Făgăraș Mts. & Investigate the naturalness of the TE by comparing it with an annual $3^{\circ} \mathrm{C}$ isotherm. \\
\hline $\begin{array}{l}\text { Rob \& Taut (2007), } \\
\operatorname{Rob}(2008)\end{array}$ & Gutâi Mts. & $\begin{array}{l}\text { According to the authors, the upper limit of beech in Gutâi massif (1442 m a.s.l.) is a natural limit (identified } \\
\text { on the basis of forest density, and tree shapes). }\end{array}$ \\
\hline Kern \& Popa (2008) & Călimani Mts. & $\begin{array}{l}\text { Dendrochronological study of Pinus cembra. They found a } 65 \text { meter upward migration at the treeline. Produced } \\
\text { a hypothesis about the decrease of frost associated with global warming, which would reduce stress in the } \\
\text { timberline ecotone. }\end{array}$ \\
\hline Guzik (2008) & Tatra Mts. & $\begin{array}{l}\text { Photo interpretation and remote sensing analysis of the functioning of the recent timberline and the environ- } \\
\text { ment above it. Indicates the maximum and minimum ranges of the forest, confirmed the impact of a mass- } \\
\text { elevation effect and the "valley phenomena". The timberline changes between } 1955 \text { and } 2004 \text { were conducted } \\
\text { in the Polish Tatra Mts. }\end{array}$ \\
\hline Sitko \& Troll (2008) & Western Chornohora & $\begin{array}{l}\text { Interpretation of recent and historical maps (scale } 1: 100,000 \text { ). Observed the altitude timberline increase } \\
\text { of } 80 \mathrm{~m} \text { between } 1933 \text { and } 2001 \text {. Area above the timberline shrank by } 30 \% \text {. The biggest changes are associ- } \\
\text { ated with spruce forest far away from working livestock farms. The lowest changes are connected with decidu- } \\
\text { ous timberlines near the farms. }\end{array}$ \\
\hline
\end{tabular}




\begin{tabular}{|c|c|c|}
\hline Author (year) & Study area & The most important results \\
\hline Kricsfalusy et al. (2008) & Ukrainian Carpathians & $\begin{array}{l}\text { Reconstruction of timberline changes based on 1852-1964 maps and LANDSAT images. (Extensive article but } \\
\text { without citation and clear methodology). }\end{array}$ \\
\hline Kuemmerle et al. (2009) & Ukrainian Carpathians & $\begin{array}{l}\text { Forest cover changes between } 1988 \text { and } 2007 \text { based on LANDSAT images. Illegal logging had an impact on } \\
\text { forest cover. The forest cover decreased in the central part of the region. }\end{array}$ \\
\hline $\begin{array}{l}\text { Czajka (2010), } \\
\text { Kalafarski (2011) }\end{array}$ & Polish Tatra Mts. & $\begin{array}{l}\text { The authors analysed the timberline changes in the last } 50 \text { years (Guzik 2008) and provide a dendrochronologi- } \\
\text { cal examination of progressive and stable timberlines of different types (anthropogenic, edaphic, and climatic). } \\
\text { Significant differences in the conditions and age structures of the spruce forests confirms their different origins. }\end{array}$ \\
\hline Martazinova et al. (2011) & Ukrainian Carpathians & $\begin{array}{l}\text { Analysis of treeline changes affected by recent climate changes. The coniferous treeline increased at higher } \\
\text { altitudes in contrast to the deciduous treeline which was stable or decreased. Those changes were not related } \\
\text { with climate change. }\end{array}$ \\
\hline Kucsicsa $(2011,2013)$ & Rodnei Mts. & $\begin{array}{l}\text { Photo interpretation analysis of satellite images as a source of information about timberline changes. Particular } \\
\text { attention was paid to the human influence. }\end{array}$ \\
\hline $\begin{array}{l}\text { Török-Oance R. } \\
\text { \& Török-Oance M. (2012) }\end{array}$ & Tarcău Mts. & $\begin{array}{l}\text { Case study based on the LANDSAT satellite images and historical maps (1950s), where the timberline changes } \\
\text { were analysed. The changes were associated with the termination of grazing } 20 \text { years ago. }\end{array}$ \\
\hline Knorn et al. (2012) & Romanian Carpathians & $\begin{array}{l}\text { The authors examined the effectiveness of protected areas in Romania, with the help of LANDSAT satellite } \\
\text { images from the } 1995-2005 \text { period. It was found, that the loss in protected forests is even greater than in the } \\
\text { adjacent regions. The national parks effectiveness of biodiversity protection decreases. }\end{array}$ \\
\hline Tanase (2013) & Giumalău Mts.* & $\begin{array}{l}\text { Used historical maps (scale } 1: 100,000 \text { ) and LANDSAT images to detect timberline / treeline changes during } \\
\text { last } 150 \text { years. The timberline increased about } 113 \mathrm{~m} \text { to almost } 1550 \mathrm{~m} \text { a.s.l. (There is a lack information about } \\
\text { methodology.) }\end{array}$ \\
\hline $\begin{array}{l}\text { Shandra et al. (2013), } \\
\text { Weisberg et al. (2013) }\end{array}$ & Carpathians $^{\star}$ & $\begin{array}{l}\text { Changes in TE ecotone in the last } 130 \text { years on the basis of historical maps and LANDSAT images the forest } \\
\text { cover increased were observed in timberline ecoton ( } 34 \% \text { of all afforestations). The impact of global warming } \\
\text { and land use were analysed. The changes in timberline altitude are related with: slope steepness, shrub cover } \\
\text { above it, elevation and distance to sheds. }\end{array}$ \\
\hline Griffiths et al. (2014) & Carpathians * & $\begin{array}{l}\text { Remote sensing analysis of land covers changes change during six, five-year periods from } 1988 \text { to } 2010 \text {. Au- } \\
\text { tomatic classification was used for the entire Carpathian Mountains. The share of mixed and coniferous forest } \\
\text { were shown to have especially decreased, while deciduous forest increased. The results indicated that forest } \\
\text { cover has likely increased locally, due to abandoned agriculture or afforestation policies. Almost } 20 \% \text { of the } \\
\text { forests in the study area experienced disturbances. }\end{array}$ \\
\hline Munteanu et al. (2014) & Carpathians * & $\begin{array}{l}\text { Meta-analysis of land-cover changes over the past } 250 \text { years in the Carpathians, based on } 66 \text { existing papers. } \\
\text { Forest cover changes were dependent on the political situation and the changes taking place in agriculture. }\end{array}$ \\
\hline
\end{tabular}


The research in the Slovakian Carpathians: the Malá Fatra Mountains, Vel'ká Fatra Mountains, Nízke Tatry Mountains, and the Chočské Vrchy Mountains (514.4, 514.53, 514.8, 514.9) was conducted by Plesník (1955, 1956, 1957, 1958, 1966, 1978). More recently, research was done concerning the restoring of spruces below the timberline in the Nízke Tatry Mountains by Gubka (1996), Gubka \& Pittner (2013). Numerous works by Slovakian researchers have been botanical studies on the alpine layer vegetation (Doležal \& Šrůtek 2002) and studies in the range of forest sciences, dealing with restoration and planting in a timberline ecotone (Kucbel 2001; Seben 2005).

The issue of timberline in the contemporary Ukrainian Carpathians and the Western Bieszczady Mountains (522 and 523) was widely discussed by Polish researchers until the mid-20th century (until the change of state boundaries). The research work was carried out in Pokuts'ko-Bukovins'ki Karpati Mountains (522.16, 523.1) (Zapałowicz 1889), in the Chornohora Mountains (522.25) (Wóycicki 1930; Środoń 1948), in Gorgany Mountains (522.15) (Jakób 1937), and in Chyvchyns'ki Hory Mountains (a range of the Maramureșului Mountains 523.1) (Środoń 1948). The impact of grazing on the environment of the Eastern Beskids was examined by Kubijowicz (1926). Most research in this region focuses on the lack of the upper spruce section and the reasons for this lack, in the Lesiste and Poloninskie Beskids (Kubijowicz 1926; Środoń 1948; Zarzycki 1963; Zientarski 1985). In the last few years, the research has concentrated on the timberline changes since the mid-19th century with regard to post-socialist transformation and contemporary climatic changes - in the Ukrainian Carpathians (Kricsfalusy et al. 2008; Kuemmerle et al. 2009; Martazinova et al. 2011; Baumann et al. 2011), in the Western Bieszczady Mountains (Kucharzyk 2006; Kucharzyk \& Augustyn 2008; Augustyn \& Kucharzyk 2012) or in the Western Chornohora Mountains (Sitko \& Troll 2008).
The timberline in the Romanian Carpathians is the least known one. Geanana was the precursor of the research on the timberline in this region. He studied the impact of the altitude and mass-elevation effect, on the location of the timberline (1972, 1975, 1991, 1996, 2004) in the Retezat Mountains (531.32). Cenuşă (2000) carried out studies on forest ecology in its uppermost ranges. In the Făgăraş Mountains (531.15) the timberline positions were compared to the annual isotherm of $3^{\circ} \mathrm{C}$ (Török-Oance et al. 2006). The influence of human activity in part of the Tarcu Mountains was analysed as well (Török-Oance R. \& Török-Oance M. 2012). There are also studies on the timberline in the Rodna Mountains (523.3) (Kucsicsa 2011), in the Gutâi Mountains (523.56) (Rob \& Taut 2007; Rob 2008) and in the Giumalău Massif (523.42) (Tanase 2013), however, these studies were quite superficial and the authors did not present the methodological assumptions they had made in their work.

Aerial photographs are widely used as sources of information in the research on environmental changes. The photos have been used to show changes which have occurred in the last 150 years since aero-photography developed. Photo interpretation of multitemporal aerial images may be applied extensively in the studies on the succession of biocenoses, the activity and changeability of geomorphological processes (Van Westen \& Getahun 2003), forest cover transformations (Fensham \& Fairfax 2002; Paterek \& Olędzki 2005), krummholz zone regeneration (Švajda et al. 2011) or timberline changes (Luo \& Doi 2013). Plesník (1973) was one of the first researchers to use aerial photos as a source of information on the changes of timberline location in the Carpathians. Nowadays, the method has been used by M. Guzik (2008) in the spatial research on changes in the timberline ecotone of the Tatra Mountains. Stereographic aerial photographs constituted the basis for the development of the method of repeated terrestrial photography. This 
method was employed in the studies on forest cover changes in the Tatra Mountains (Kolecka \& Kaim 2010). Modern techniques and the development of satellite technologies made it possible to conduct large-scale analyses of forest cover changes (in the last 30 years) with the application of LANDSAT (and the latest projects) imaging in the entire Carpathians (Griffiths et al. 2014), the provinces (the Eastern Carpathians: Kucharzyk \& Augustyn 2008) as well as in particular massifs: Buzău Mountains (525.2) (Malek et al. 2014), the lezerul Mountains (531.14) (Mihai et al. 2007), in the Făgăraș Mountains (531.15) (Osaci-Costache \&Ene 2010), the Bucegi Mountains (531.14) (Mihai et al. 2006), in the Rodna National Park (Knorn et al. 2012; Kucsicsa 2013), in the Marmarosh National Park, and the Călimani Landscape Park (Knorn et al. 2012), which are indirectly affected by the timberline problems. Comparative analyses of land development on historical and modern maps have a lower accuracy $(1: 75,000$ or 1: 100,000 scale) (Sitko \& Troll 2008; Kricsfalusy et al. 2008). However, the historical and modern maps are often characterised by a longer timespan: reaching to about 150 years back.

There are only four studies on the timberline for the entire Carpathians. One of the studies is a monograph from 100 years ago (Fekete \& Blattny 1913-1914), another study is a synthetic picture by an American and Ukrainian team of researchers (Shandra et al. 2013; Weisberg et al. 2013), and another is a description of the influence of global factors on the timberline position (Czajka et al. 2015b). Some fragments of the Carpathians massifs were not examined. For example, the southern slopes of the Southern Carpathians which were outside the former Austro-Hungarian Empire, were studied in only one of them. A meta-analysis drawn up by a team of American, Polish, Ukrainian, Slovakian, Hungarian, and Czech researchers constitutes an important study on the forest cover changes in the Carpathians (Munteanu et al. 2014).

\section{Research on the forest in the subalpine zone on the Babia Góra Mountain}

The subalpine forests and the timberline in the Babia Góra National Park have been examined thoroughly (Walas 1933; Celiński \& Wojterski 1961, 1963, 1978; Holeksa 1998; Kasprowicz 1980; Fabijanowski \& Gądek 1983; Zientarski 1985; Awzan et al. 1986-1987), however, there is not enough data from the Slovakian part of the massif (Vorčák et al. 2006b), and especially comprehensive studies on the whole massif (Tuček et al. 2004). Owing to their semi-primeval character, the uniqueness of the Babia Góra forests has been discussed by almost all researchers interested in this region (Szwagrzyk et al. 1996, 1997). They may constitute an excellent reference point in assessing the natural character of other forest areas. However, it has been pointed out that biocenoses transformed in the past, and currently undergoing a process of spontaneous renaturisation, are not uncommon here (Holeksa et al. 2004).

The timberline ecotone mainly consists of Norway spruce Picea abies (Jaworski \& Kaczmarski 1989, 1995) with mountain-ash Sorbus aucuparia (Borysiak 1974, 1985). Several authors have also examined the issue of the Babia Góra spruce forest age structure (Zientarski 1976), concluding that there is a shortage of young specimens (under 80 years) and specimens older than 200 years. The oldest specimens reach the age of 360 (Bednarz et al. 2002), or even 400 years (Czajka unpublished data).

The first notes on the vegetation and layer character of Babia Góra were made by Staszic (1815) in the first half of 19th century. Zapałowicz (1879) was the first researcher who conducted a systematic study on the subalpine forest, and in particular, on the timberline in this region. He described the ranges of particular plant species and determined the uppermost range of the spruce forest timberline. Anthropogenic and natural factors affecting the timberline were studied by Kasprowicz (1980) 
and Zientarski $(1985,1989)$. There are no such studies for the Slovakian section of this part of the massif and no analyses of the timberline changes throughout the last century.

Zientarski (1976), Awzan et al. (1986-1987), and Vorčák et al. (2006a) carried out research on the changes of the stand structure and density, and the changes of spruce morphology with the increase of altitude in the Polish and Slovakian part of the massif. In harsh environmental conditions, generative reproduction is strongly limited. Thus, vegetative reproduction from roots and branches of older specimens predominates. This problem was examined in the Slovakian part of the massif by Vorčák \& Jankovic (2009). Changes in temperature are the most significant factor differentiating stands in a vertical profile (Czajka 2012).

The history of economic exploitation of forests together with the grazing management had been discussed (Kubijowicz 1927; Zabielski et al. 1969, Jostowa 1972; Dzięciołowski 1963), but the data is fragmentary and synthetic analyses were impossible.

\section{Conclusions and research needs}

1. The Norway spruce (Picea abies L. Karst) or the European beech (Fagus sylvatica) are the main forest forming species of the Carpathian timberline. These species have different ecological demands, spatial patterns, and sensitivity to environmental changes. The beech timberline is more stable: its course in the Western Bieszczady Mountains has moved by only $10 \mathrm{~m}$ in the last 150 years. In the case of the spruce timberline, its succession and expansion into higher altitudes has been observed in many location in the Carpathians: in the Western Chornohora Mountains the spruce timberline has shifted upslope by $80 \mathrm{~m}$ in the last 70 years.

2. The natural, undisturbed location of a timberline depends on climatic factors, especially temperature. The climatic limit for the dense forest of the upper wooded section is defined in various ways - it corresponds to $10^{\circ} \mathrm{C}$ isotherm of the warmest month, among other things. However, as much as $95 \%$ of the timberline course in the Carpathians runs below the climatic limit determined in such a way.

3. Despite temperature, the distance of a particular massif from the Poles and the massif's mass-elevation effect are global factors which affect the timberline. In the Carpathians, the average elevation of the timberline decreases by $70 \mathrm{~m}$ with every degree of latitude, while the timberline's changeability within the macro-region results from the varied mass-elevation effect.

4. A number of local factors have an impact on the timberline course in the Carpathians. Among the most significant natural factors are: the occurrence, intensity and dynamics of violent geomorphological processes, and the local relief (its variation, exposition, and gradients). Other natural elements are of secondary importance, while the influence of physiological factors (the impact of physiological drought, mycorrhizal fungi or tree regeneration, and sapling survival etc.) has not been determined thoroughly enough yet.

5. Research indicates that factors which are variable in time (anthropogenic activity and climatic conditions) cause disturbances in the timberline environment. Stable environmental factors (invariable throughout a long period of time: microtopography, soil cover, etc.) are responsible for the timberline site patterns.

6. Nevertheless, throughout the centuries, human activity has had the biggest influence on the Carpathian timberline dynamics. Since the 12th century and the times of Wallachian colonisation, the anthropogenic activity has affected the timberline leading to a downslope shift of the timberline of even $700 \mathrm{~m}$ in some massifs. Pasturing and clearing - related pressure were most intense in the 18th and 19th century. In the 20th century, the downslope shift of the timberline increased owing to the growth of environmental pollution and the development of tourism. However, since the 1920s different forms of this ecotone 
preservation have been introduced. The political and economic situation of the Carpathian countries at the end of the 20th century (the fall of communism and system transformation), led to abandoning pasturage, and increasing forest areas. As a result of these processes, $34 \%$ of the Carpathian timberline has shifted upslope to higher altitudes in the last 120 years.

7. The highest upper wooded section zone is divided and defined in various ways. Sometimes the authors do not define the applied terminology and in different articles the same term can be understood in a different way. This ambiguity refers to virtually all the terms regarding the final zone of the upper wooded section (timberline, treeline, forestline, tree species line). The authors of comparative analyses who employ available results of the research into this Carpathian zone, should consider and be aware of these differences.

8. The timberline was the subject of a lot of scientific research from the second half of the 19th century up to the 1970s. Further analyses have become more widespread since 2006. Nowadays this topic is widely discussed. With regard to geographic dimension it may be observed that there

\section{References}

AAS B., 1964. Björke - og barskoggrenser in Norge: En undersökelse av de övre klimatiskeskoggrenser. Hovedfagsoppgave i naturgeografi, University of Oslo.

Adamczyk B., Gerlach T., Obrebska-Starklowa B., StARKEL L., 1980. Zonal and azonal aspects of the agriculture-forest limit in the Polish Carpathians. Geographia Polonica, vol. 43, pp. 71-84.

Allen T.F.H., StarR T.B., 1982. Hierarchy: Perspectives for ecological diversity. Chicago, Ilinois: University of Chicago Press.

Armand D.L., 1980. Nauka o krajobrazie. Podstawy teorii i metody logiczno-matematyczne. Warszawa: Państwowe Wydawnictwo Naukowe. is a disproportion in the quantity and quality of existing studies between the Romanian Carpathians and the remaining massifs. Therefore, they constitute a significant potential for the studies on the environment of the timberline ecotone.

9. The perspectives of future scientific research into the Carpathian timberline are connected with the ongoing transformations of the timberline caused by contemporary climatic and athropopressure-related changes. The effect of climate warming within the timberline is concealed by the natural succession of a forest combined with the reduction of anthropopressure.

\section{Acknowledgements}

The work described here forms part of research project NN 306070640 of the Polish National Science Centre, entitled Natural and anthropogenic conditioning of the occurrence of the timberline on Babia Góra Mountain, and its dynamics over the last 200 years.

\section{Editors' note:}

Unless otherwise stated, the sources of tables and figures are the author's, on the basis of their own research.

Arno S., 1984. Timberline: Mountain and Arctic forest frontiers. Washington: The Mountaineers.

Augustyn M., KuCharzYK S., 2012. Górna granica lasu na terenie wsi Ustrzyki Górne i Wołosate w końcu XVIII wieku. Roczniki Bieszczadzkie, 20, pp.15-27.

Aulitzky H., TuRner H., 1982. Bioklimatische Grundlagen einer standortsgemäßen Bewirtschaftung des subalpinen Lärchen-Arvenwaldes. Mitteilungen Eidgenössische Anstalt für das Forstliche Versuchswesen, vol. 58, no. 4, pp. 327-580.

AWZAN L., Kasprowicz M., WęGLARSKI K., 1986-1987. Zmienność górnoreglowego boru karpackiego oraz morfologia świerka przy górnej granicy lasu na północnych zboczach Babiej Góry. Rocznik Dendrologiczny, 37, pp. 5-24. 
BALON J., 1995. The upper forest limit in the Tatra mountains as a physico-gepgraphical line. Enviromental aspects of the timberline in Finland and in the Polish Carpathians. Zeszyty Naukowe UJ. Prace Geograficzne, 98, Kraków: Wydawnictwo Uniwersytetu Jagielońskiego, pp. 171-187.

BALON J., 2000. Z metodyki prowadzenia granic regionów fizycznogeograficznych w górach. Problemy Ekologii Krajobrazu, 7, pp. 33-47.

BALON J., 2001. Podatność geosystemów górskich na zmiany antropogeniczne [in:] K. German, J. Balon (eds.), Przemiany środowiska przyrodniczego Polski a jego funkcjonowanie. Problemy Ekologii Krajobrazu, 10, pp. 765-771.

BALON J., 2007. Stabilność środowiska przyrodniczego Karpat Zachodnich powyżej górnej granicy lasu. Kraków: Instytut Geografii i Gospodarki Przestrzennej Uniwersytetu Jagiellońskiego.

BARRY R.G., VAN WIE C.C., 1974. Topo- and microclimatology in alpine areas [in:] J.D. Ives, R.G. Barry (eds.), Arctic and Alpine Environments. London: Methuen, pp. 73-83.

Baumann M., Kuemmerle T., Elbakidze M., Ozdogan M., Radeloff V.C., Keuler N.S., Prishchepov A.V., Kruhlov I., Hostert P., 2011. Patterns and drivers of post-socialist farmland abandonment in Western Ukraine. Land Use Policy, vol. 28, no. 3, pp. 552-562.

Bednarz Z., Jaroszewicz B., Ptak J., Szwagrzyk J., 2002. Dendrochronology of Norway spruce (Picea abies L. Karst.) from the Babia Góra National Park. Dendrochronologia, 16-17, pp. 45-55.

Bednorz F., 2000. Der Abbau der organischen Substanz im Waldgrenzökoton am Stillberg (Dischmatal/Schweiz). Arbeiten aus dem Institut für Landschaftsökologie, 7, Münster: Westfälische Wilhelms-Universität.

BONAN G.B., 1992. Soil temperature as an ecological factor in boreal forests [in:] H.H. Shugart, R. Leemans, G.B. Bonan (eds.), A system analysis of the global boreal forest. Cambridge: Cambridge University Press, pp. 126-143.

BorYSIAK J., 1974. Zarośla jarzębiny (Sorbus aucuparia L. var. glabrata Wimm. Et Gra) w strefie górnej granicy lasu w masywie Babiej Góry. Poznań: Zakład Ekologii Roślin i Ochrony Środowiska Uniwersytetu Adama Mickiewicza [MA thesis].

BORYSIAK J., 1985. Zespół jarzębiny Athyrio-Sorbetum ass. Nova w strefiegórnej granicy lasu masywu Babiej Góry (Beskid Zachodni). Badania
Fizjograficzne nad Polską Zachodnia, seria B: Botanika, vol. 36, pp. 115-132.

Boysen-Jensen P., 1949. Causal plant geography. Dansk.Vedensk.Selsk. Biology and Medicine, vol. 21, 3 pp.

Brockmann-JerosCH H., 1919. Baumgrenze und Klimacharakter.Beitr. Geobot.Landesaufnahme, vol. 6, $252 \mathrm{pp}$.

Cadenasso M.L., Pickett S.T., Weathers K.C., Bell S.S., Benning T.L., Carreiro M.M., Dawson T.E., 2003. An interdisciplinary and synthetic approach to ecological boundaries. BioScience, vol. 53, no. 8, pp. 717-722.

CAIRNS D.M., 1998. Modelling controls on pattern at alpine treeline. Geographical Environmental Modelling, vol. 2, no. 1, pp. 43-63.

Cairns D.M., Malanson G.P., 1998. Environmental variables influencing the carbon balance at the alpine treeline: A model approach. Journal of Vegetation Science, vol. 9, no. 5, pp. 679-692.

Callaway R.M., 1998. Competition and facilitation on elevation gradients in subalpine forests of the northern Rocky Mountains, USA. Oikos, vol. 82, no. 3, pp. 561-573.

Carcalllet C., Brun J.J. 2000. Changes in landscape structure in the north western Alps over the last 7000 years: Lessons from soil charcoal. Journal of Vegetation Science, vol. 11, no. 5, pp. 705-714.

CelińSKI F., Wojterski T., 1961. Mapa zbiorowisk roślinnych Babiogórskiego Parku Narodowego. Poznań: Poznańskie Towarzystwo Przyjaciół Nauk. Wydział Matematyczno-Przyrodniczy.

Celinśsi F., WoJterski T., 1963. Świat roślinny Babiej Góry [in:] W. Szafer (ed.), Babiogórski Park Narodowy. Kraków: Zakład Ochrony Przyrody PAN, pp. 109-170.

CelińSKI F., Wojterski T., 1978. Zespoły leśne masywu Babiej Góry. Poznań: Poznańskie Towarzystwo Przyjaciół Nauk, Prace Komisji Biologicznej, vol. 48, 62 pp.

Cenușă R., 2000. Cercetări asupra dinamicii structurale a ecosistemelor de pădure de la limita altitudinală de vegetație pentru menținerea echilibrului ecologic. Referat științific final ICAS.

Cogbill C.V., White P.S., 1991. The latitude-elevation relationship for spruce-fir forest and treeline along the Appalachian Mountain chain. Vegetatio, vol. 94, no. 2, pp.153-175. 
CZAJKA B., 2010. Środowiskowe uwarunkowania przebiegu górnej granicy lasu w polskich Tatrach Zachodnich. Sosnowiec: Uniwersytet Śląki. Wydział Nauk o Ziemi. Katedra Paleogeografii i Paleoekologii Czwartorzędu [MA thesis].

CZAJKA B., 2012. Wpływ wysokości n.p.m. na wrażliwość klimatyczna świerka pospolitego w masywie Babiej Góry. Studia i Materiały Centrum Edukacji Przyrodniczo-Leśnej, vol. 14, no. 1, pp. 91-97.

CZAJKA B., ŁauCZAK A., KACZKA R.J., 2015a. The $d y$ namics of the timberline ecotone on the asymmetric ridge of the Babia Góra Massif, Western Carpathians. Geographia Polonica, vol. 88, no. 2, pp. 85-102.

CZAJKA B., ŁaJCZAK A., KaCZKA R.J., 2015b. Geographical characteristic of the recent timberline in the Carpathians. Geographia Polonica, vol. 88, no. 2, pp. 35-54.

Danielewicz W., Zientarski J., 2004. Uwagi na temat procesów dynamiki lasu w reglu górnym Karkonoskiego Parku Narodowego [in:] J. Štursa, K.R. Mazurski, A. Palucki, J. Potocka (eds.), Geoekologické problémy Krkonoš. Sborník Mezinárodní vědecké konferencje: Listopad 2003, Szklarska Poręba, Opera Corcontica, 41, pp. 324-335.

DÄNIKER A., 1923. Biologische Studien uber Baumund Waldgrenze, insbesondere uber die Klimatischen Ursachen und deren Zusammenhange. Vierteljahrsschrift der Naturforschenden Gesellschaft in Zürich, 68, Zürich: Naturforschende Gesellschaft.

Daubenmire R., 1954. Alpine timberlines in the Americas and their interpretation. Butler University Botanical Studies, vol. 11, art. 14, pp.119-136.

Di Castri F., Hansen A.J., Holland M.M. (eds.), 1988. A new look at ecotones, emerging international projects on landscape boundaries. Biology International: Special issue, 17, Paris: International Union of Biological Sciences.

DI QUERVAIN A., 1904. Die hebung der atmosphärischen Isothermen in den Schweizer Alpen und ihre beziehung zu den Höhengrenzen, Leibzig, $53 \mathrm{pp}$.

DoBRZAŃSKI B., 1995. Gleboznawstwo. Warszawa: Państwowe Wydawnictwo Rolnicze i Leśne.

DoležAl J.ŠrưTeK M., 2002. Altitudinal changes in composition and structure of mountain-temperate vegetation: a case study from the Western Carpathians. Plant Ecology, vol. 158, no. 2, pp. 201-221.
Donaubaur E., 1963. Über die Schneeschütte-Krankheit(Phacidium infestans KARST.) der Zirbe (Pinus cembra L.) und einige Begleitpilze. Mitteilungen der forstlichen Bundesversuchsanstalt Mariabrunn, 60, pp. 575-600.

DZıĘCIOŁOWSKI R., 1963.Z historii gospodarki leśnej na Babiej Górze [in:] W. Szafer (ed.), Babiogórski Park Narodowy, Kraków: Zakład Ochrony Przyrody PAN, pp. 235-241.

ElLenBerg H., 1963. Vegetation Mitteleuropas mit den Alpen in kausaler, dynamischer und historischer Sicht. Stuttgart: Ulmer.

FABIJANOWSKI J., 1955. Lasy tatrzańskie [in:] W. Szafer (ed.), Tatrzański Park Narodowy, Kraków: PAN, pp. 73-131.

FabiJAnOWSKI J., GąDEk K., 1983. Lasy Babiej Góry [in:] K. Zabierowski (ed.), Park Narodowy na Babiej Górze. Przyroda i Człowiek, Studia Naturea: Seria B, 29, Warszawa-Kraków: Zakład Ochrony Przyrody i Zasobów Naturalnych PAN, Państwowe Wydawnictwo Naukowe, pp. 179-196.

FALL J., 2007. Designing framework conventions to promote and support trans boundary protected areas: theory and practice from the Carpathian Convention [in:] Biodiversity and protected areas: The Italian and Ukrainian legislation, Milano: Giuffrè Editore, pp. 101-117.

Fang J.Y., Oshawa M., KIRA T., 1996. Vertical vegetation zones along $30^{\circ} \mathrm{N}$ latitude in humid East Asia. Vegetatio, vol. 126, no. 2. pp. 135-149.

Fekete L., BlatTny T. 1913-1914. Die Verbreitung der forstlich wichtigen Bäume und Sträucher um ungarischen Staate. Selmecbánya: A.J. Witwe.

FELIKSIK E., WILCZYŃSKI S., 2000. Dendroclimatological analysis of the Norway spruce (Picea abies (L.) Karst.) from the Beskid Ślaski Mountains. Zpravodaj Beskydy, 13, pp. 161-170.

Fensham R.J., Fairfax R.J., 2002. Aerial photography for assessing vegetation change: A review of applications and the relevance of findings for Australian vegetation history. Australian Journal of Botany, vol. 50, no. 4, pp. 415-429.

Fleischer P., Godzik B., Bicarova S., Bytnerowicz A., 2005. Effects of air pollution and climate change on forests of the Tatra Mountains, Central Europe [in:] K. Omasa, I. Nouchi, L.J. De Kok (eds.), Plant responses to air pollution and global change, 3 , Tokyo: Springer, pp. 111-121.

Forman R.T.T, GORDOn M., 1986. Landscape ecology. New York: J. Wiley and Sons. 
Friedel H., 1967. Verlauf der alpinen Waldgrenze im Rahmen anliegender Gebirgsgelände. Mitteilungen der forstlichen Bundes-Versuchsanstalt Mariabrunn, 75, pp. 81-172.

FRIES T.C.E., 1913. Botanische Untersuchungen im nördlichsten Schweden: Ein Beitrag zur Kenntnis der alpinen und subalpinen Vegetation in Torne Lappmark. Vetenskapliga och praktiska undersökningar i Lappland, Flora ich Fauna, 2, Uppsala: Almqvist \& Wiksells.

Geanana M., 1972. L'influence de l'altitude et de la massivité sur la limite supérieure de la forêt dans les Carpates Roumaines. Travaux du Symposium de Géographie Physique des Carpates, Institutul de Geografie, Academia Română, București, pp. 417-424.

GEANANA M., 1975. Superior limit of the forest in the Retezat Mountains. University of Bucharest. Faculty of Geology - Geography [PhD thesis].

GEANANA M., 1991. The influence of geographical position on the upper tree line in the Romanian Carpathians. Studii Universitatis Babes-Bolyai: Geographia, 40-41, pp. 61-63.

GEANANA M., 1996. Influența antropică asupra limitei superioare a pădurii în Munții Retezat. Annals of University from Bucharest, 45, pp. 39-44.

Geanana M., 2004. Limita superioara a padurii in Muntii Retezat. Bucharest: Universitatii Bucuresti.

Geiger R., 1961. Das Klima der bodennahen Luftschichten. Anzeiger für Schädlingskunde, vol. 34, no. 10, pp. 159-159.

GERMAN K., 2000. Obiektywizm i subiektywizm w wydzielaniu granic fizyczno-geograficznych [in:] M. Pietrzak (ed.), Granice krajobrazowe podstawy teoretyczne i znaczenie praktyczne. Problemy Ekologii Krajobrazu, 7, pp. 155-166.

GolDEWIJK K.K., 2001. Estimating global land use change over the past 300 years: The HYDE Database. Global Biogeochemical Cycles, vol. 15, no. 2, pp. 417-433.

Gosz J.R., Sharpe P.J.H., 1989. Broad-scale concepts for interactions of climate, topography, and biota at biome transitions. Landscape Ecology vol. 3, no. 3-4, pp. 229-243.

Grace J., 1977. Plant response to wind. London: Academic Press.

GRACE J., 1989. Tree lines. Philosophical Transactions of the Royal Society. Series B, 324, pp. 233-245.

Grace J., Morton A., 1990. Climate and growth of Pinus sylvestris at its upper altitudinal limit in Scotland. Evidence from tree growth-ring. Journal of Ecology, vol. 78, no. 3, pp. 601-610.

Griffiths P., Kuemmerle T., Baumann M., Radeloff V.C., Abrudan I.V., Lieskovsky J., Munteanu C., Ostapowicz K., Hostert P., 2014. Forest disturbances, forest recovery, and changes in forest types across the Carpathian ecoregion from 1985 to 2010 based on Landsat image composites. Remote Sensing of Environment, 151, pp. 72-88.

GUBKA K., 1996. Stav porastov v hornej hranici lesa na LS Čierny Váh [in:] J. Ilavský (ed.), Biologické, technické a ekonomické princípy obhospodarovania lesov pre ich nepretržitý rozvoj, Vedecke prace Lesnickeho vyskumneho ustavu vo Zvolene (Slovak Republic), 41, pp. 171-176.

GubkA K., PITTNer J., 2013. Change of stand structure in upper tree line caused by disturbances. Beskydy, vol. 6, no. 1, pp. 75-86.

Guzik M., 2008. Analiza wpływu czynników naturalnych $i$ antropogenicznych na kształtowanie się zasięgu lasu i kosodrzewiny w Tatrach. Kraków: Uniwersytet Rolniczy im. Hugona Kołłątaja. Wydział Leśny. Katedra Botaniki Leśnej i Ochrony Przyrody [PhD thesis].

Hansen A.J., DI Castri F., (eds.), 1992. Landscape Boundaries: Consequences for biotic diversity and ecological flows. Ecological Studies, 92, New York: Springer-Verlag.

HASELWANDTER K., 2007. Mycorrhiza in the alpine timberline ecotone: Nutritional implications [in:] G. Wieser, M.Tausz (eds.), Trees at their upper limit: Treelife limitation at the alpine timberline, Plant Ecophysiology, 5, Dordrecht: Springer, pp. 57-66.

Hasselquist N., Germino M.J., McGonigle T., SMITH W.K., 2005. Variability of Cenococcum colonization and its ecophysiological significance for young conifers at alpine-treeline. New Phytologist, vol. 165, no. 3, pp. 867-873.

HAVRANEK W.M., 1993.The significance of frost and frost-drought for the alpine timberline [in:] T. Anfodillom, C. Urbinati (eds.), Ecologia delle foreste d'alta quota, Atti del XXX Corso di Cultura in Ecologia, 30, pp.115-127.

Havranek W.M., Tranquillini W., 1995. Physiological processes during winter dormancy and their ecological significance [in:] W.K. Smith, T.M. Hinckley (eds.), Ecophysiology of coniferous forests, San Diego: Academic Press, pp. 95-124. 
Heckman K., Welty-Bernard A., Rasmussen C., SCHWARTZ E., 2009. Geologic controls of soil carbon cycling and microbial dynamics in temperate conifer forests. Chemical Geology, vol. 267, pp. 12-23.

Hermes K., 1955. Die Lage der oberen Waldgrenze in den Gebirgen der Erde und ihr Abstand zur Schneegrenze. Kölner Geographische Arbeiten 5.

Hess M., 1965. Piętra klimatyczne w polskich Karpatach Zachodnich. Zeszyty Naukowe Uniwersytetu Jagiellońskiego. Prace Instytutu Geograficznego, 33, Kraków: Uniwersytet Jagielloński.

Hoch G., Popp M., KöRner C., 2002. Altitudinal increase of mobile carbon pools in Pinus cembra suggests sink limitation of growth at the Swiss treeline. Oikos, vol. 98, no. 3, pp. 361-374.

HOCH G., KöRnER C., 2003. The carbon charging of pines at the climatic treeline: A global comparison. Oecologia, vol. 135, no. 1, pp. 10-21.

HoleKSA J., 1998. Rozpad drzewostanu i odnowienia świerka, a struktura i dynamika karpackiego boru górnoreglowego. Monographiae Botanicae, 82, Warszawa: Polskie Towarzystwo Botaniczne.

Holeksa J., Szwagrzyk J., Musiałowicz W., Parusel J., 2004. Struktura i dynamika lasów Babiogórskiego Parku Nardowego [in:] B.W. Wołoszyn, A. Jaworski, J. Szwagrzyk (eds.), Babiogórski Park Narodowy. Monografia Przyrodnicza, Kraków: Wydawnictwo i Drukarnia Towarzystwa Słowaków w Polsce, pp. 527-598.

Holtmeier F.K., 1974. Geooekologische Beobachtungen und Studien an der subarktischen und alpinen Waldgrenze in vergleichender Sicht. Wiesbaden: Franz Steiner.

Holtmeler F.K., 1981. What does the term Krummholz really mean? Observations with special reference to the Alps and the Colorado Front Range. Mountain Research and Development, vol. 1, no. 3-4, pp. 253-260.

Holtmeler F.K., 1996. Der Wind als landschaftsökologischer Faktor in der subalpinen und alpinen Stufe der Front Range, Colorado [in:] F.K. Holtmeier (ed.), Beiträge aus den Arbeitsgebieten am Institut für Landschaftsökologie, Institut für Landschaftsökologie, Arbeiten aus dem Institut für Landschaftsökologie, Westfälische Wilhelms-Universität, Münster: Institut für Landschaftsökologie der Westfälischen Wilhelms-Universität, pp. 19-45.
Holtmeler F.H., Broll G., 2007. Treeline advance - driving processes and adverse factors. Landscape Online, 1, pp. 1-33.

Holtmeler F.K., 2009. Mountain timberlines: Ecology, patchiness, and dynamics. Advances in Global Change Research, 36, Dordrecht: Springer.

HustiCH I., 1953. The boreal limits of conifers. Arctic, vol. 6, no. 2, pp. 149-162.

IMHOF E., 1900. Die Waldgrenze in der Schweiz, Gerlands Beitr. Gerland's Beitrage zur Geophysik, vol. 4, no. 3, pp. 241-330.

IVES J.D., 1978. Remarks on the stability of timberline [in:] C. Troll, W. Lauer (eds.), Geoecological relations between the southern temperate zone and the tropical mountains, Wiesbaden: Steiner Verlag, pp 313-318.

JAKÓB M.L., 1937. Uwagi nad górna granica lasu w Gorganach Centralnych. Sylwan, 2-3, pp.89-101.

JANOTA E., 1866. Nieco o zasięgu pionowym drzew i krzewów w Tatrach. Sprawozdanie Komisyi Fizjograficznej c.k. Towarzystwa Naukowego Krakowskiego, 1, Kraków, pp. 265-274.

JAWORSKI A., KACZMARSKI J., 1989. Budowa, struktura i dynamika górnoreglowych borów świerkowych w Babiogórskim Parku Narodowym [in:] Š. Korpel (ed.), Stav, vyvoj, produkčne schopnosti a funkce vyuzivanie lesov v oblasti Babej Hory a Pilska, Zvolen: Technická univerzita. Vysoká škola lesnícka a drevárska, pp. 122-148.

JAWORSKI A., KACZMARSKI J., 1995. Budowa, struktura, dynamika i możliwości produkcyjne górnoreglowych borów świerkowych w Babiogórskim Parku Narodowym. Acta Agraria et Silvestria, Series Silvestris, 33, pp. 75-113.

JeNÍK J., LOKVENC T., 1962. Die alpine Waldgrenze im Krkonoše Gebirge. Rozpravy Československé Akademie věd, Rada matematickych a prirodnich ved, Praha: Nakladatelstvi Ceskoslovenske Akademie ved.

JoBBÁGY E.G., JACKSON R.B., 2000. Global controls of forest line elevation in the northern and southern hemispheres. Global Ecology and Biogeography, vol. 9, no. 3, pp. 253-268.

JoDŁOWSKı M., 2007. Górna granica kosodrzewiny w Tatrach, na Babiej Górze i w Karkonoszach: struktura i dynamika ekotonu. Kraków: Instytut Geografii i Gospodarki Przestrzennej Uniwersytetu Jagiellońskiego.

JOHNSON E.A., 1987. The relative importance of snow avalanche disturbance and thinning on canopy plant populations. Ecology, vol. 68, no. 1, pp. 43-53. 
Jostowa W., 1972. Pasterstwo na polskiej Orawie. Biblioteka Etnografii Polskiej, 26, Wrocław-Warszawa-Kraków-Gdańsk: Zakład Narodowy im. Ossolińskich, Instytut Historii Kultury Materialnej PAN.

Kalafarski M., 2011. Środowiskowe uwarunkowania przebiegu górnej granicy lasu w polskich Tatrach Wysokich. Sosnowiec: Uniwersytet Ślaski. Wydział Nauk o Ziemi. Katedra Paleogeografii i Paleoekologii Czwartorzędu [MA thesis].

Kasprowicz M., 1980. Górna granica lasu na pótnocno-zachodnich zboczach Babiej Góry. Uniwersytet Adama Mickiewicza w Poznaniu. Zakład Ekologii Roślin i Ochrony Środowiska [MA thesis].

Kern Z., Popa I., 2008. Changes of frost damage and treeline advance for Swiss Stone Pine in the Calimani Mts. (Eastern Carpathians, Romania). Acta Silvatica Lignaria Hung, 4, pp. 39-48.

Kernaghan G., CuRRah R.S., 1998. Ectomycorrhizal fungi at tree line in the Canadian Rockies. Mycotaxon, 69, pp. 39-79.

Kernaghan G., 2001. Ectomycorrhizal fungi at tree line in the Canadian Rockies II. Identification of ectomycorrhizae by anatomy and PCR. Mycorrhiza, vol. 10, no. 5, pp. 217-229.

Kistowski M., 2000. Problemy oceny wrażliwości środowiska przyrodniczego na antropopresję, jako element strategicznych ocen oddziaływania na środowisko. Problemy Ocen Środowiskowych, vol. 3, no. 10, pp. 22-28.

Knorn J., Kuemmerle T., Radeloff V.C., Szabo A., Mindrescu M., Keeton W.E., Abrudan I., Griffiths P., Gancz V., Hostert P., 2012. Forest restitution and protected area effectiveness in post-socialist Romania. Biological Conservation, vol. 146, no. 1, pp. 204-212.

KoleCKA N., KaIM D., 2010. Zmiany pokrycia terenu w Tatrach Polskich określone na podstawie powtórzonej fotografii naziemnej. Prace Geograficzne. Instytut Geografii i Gospodarki Przestrzennej Uniwersytetu Jagiellońskiego, 123, pp. 31-45.

KONDRACKI J., 1978. Karpaty. Warszawa: Wydawnictwa Szkolne i Pedagogiczne.

KÖRNER C., 1998. A re-assessment of high elevation treeline positions and their explanation. Oecologia, vol. 115, no. 4, pp. 445-459.

Körner C., PAulsen J., 2004. A world-wide study of high altitude treeline temperatures. Journal of Biogeography, vol. 31, no. 5, pp. 713-732.
KÖRnER C., 2012a. Treelines will be understood, once the difference between a tree and a shrub is. Ambio, vol. 41, no. 3, pp. 197-206.

KÖRNER C., 2012b. Alpine treelines: Functional ecology of the global high elevation tree limits. Basel: Springer.

KotARBA A., 1970. The morphogenetic role of foehn wind in the Tatra Mts. Studia Geomorphologica Carpatho-Balcanica, 4, pp. 171-188.

Kotarba A., Starkel L., 1972. Holocene morphogenetic altitudinal zones in the Carpathians. Studia Geomorphologica Carpatho-Balcanica, 6, pp. 21-35.

Kotarba A., Kaszowski L., Krzemień K., 1987. High-mountain denudational system of the Polish Tatra Mountains. Geographical Studies: Special Issue, 3, Wrocław: Ossolineum.

Kotarba A., 1996. The functioning of the geoecological system of the Tatra Mountains [in:] A. Breymeyer, R.D. Noble (eds.), Biodiversity conservation in transboundary protected areas: Proceedings of an international workshop, Bieszczady and Tatra National Parks, Poland, May 15-25, 1994, Washington, DC: National Academy Press, pp. 128-134.

KotUlA B., 1889-1890. Rozmieszczenie roślin naczyniowych w Tatrach. Kraków: Polska Akademia Umiejętności.

KoZAK J., 2005. Zmiany powierzchni lasów w Karpatach Polskich na tle innych gór świata. Kraków: Wydawnictwo Uniwersytetu Jagiellońskiego.

Kricsfalusy V., Mróz W., Popov S., 2008. Historical changes of the upper tree line in the Carpathian Mountains (Ukraine). Mountain Forum Bulletin, http://mtnforum.org/sites/default/files/publication/files/1087.pdf [23 March 2015].

KuBIJOWICZ W., 1926. Życie pasterskie w Beskidach Wschodnich. Prace Instytutu Geograficznego Uniwersytetu Jagiellońskiego, 5, Kraków: Orbis.

KuBIJOWICZ W., 1927. Życie pasterskie w Beskidach Magórskich. Kraków: Polska Akademia Umiejętności.

KuCbel S., 2001. Možnosti umelej obnovy porastov pod hornou hranicou lesa [in:] M. Slodičák, J. Novák (eds), Současné otázky pestování horských lesù, Opočno: Výzkumný ústav lesního hospodářství a myslivosti, pp. 151-160.

KUCHARZYK S., 2006. Ekologiczne znaczenie drzewostanów w strefie górnej granicy lasu w Karpatach Wschodnich i ich wrażliwość na zmiany 
antropogeniczne. Roczniki Bieszczadzkie, 14, pp.15-43.

KuCharZYK S., Augustyn M., 2008. Dynamika górnej granicy lasu w Bieszczadach Zachodnich zmiany w ciagu póttora wieku. Studia Naturae, vol. 54, no. 2, pp. 133-156.

KUCSICSA G., 2011. Considerations on the timberline in the Rodna Mountains National Park. Revue Roumaine de Géographie. Romanian Journal of Geography, vol. 55, no. 1, pp. 57-61.

KuCsiCSA G., 2013. Parcul Național Munții Rodnei: Relații om - mediu. Bucuresti: Editura Universitarã.

Kuemmerle T., Chaskovskyy O., Knorn J., Radeloff V.C., Kruhlov I., Keeton W., Hostert P., 2009. Forest cover change and illegal logging in the Ukrainian Carpathians in the transition period from 1988 to 2007. Remote Sensing of Environment, vol. 113, no. 6, pp. 1194-1207.

LARCHER W., 1985. Winter stress in high mountains [in:] H. Turner, W. Tranquillini (eds.), Establishment and tending of subalpine forests: Research and management. Berichte Eidgenössische Anstalt für das Forstliche Versuchswesen, 270, pp. 11-20.

LuO G., Dol I., 2013. Detection of alpine tree line change with high spatial resolution remotely sensed data. Journal of Applied Remote Sensing, vol. 7, no. 1, 073520-073520.

Malek Ž., Scolobig A., Schröter D., 2014. Understanding land cover changes in the Italian Alps and Romanian Carpathians combining remote sensing and stakeholder interviews. Land, vol. 3, no. 1, pp. 52-73.

Malinowski E., LeWandowski W., Harasimiuk A., (eds.), 2004. Geoekologia i ochrona krajobrazu. Warszawa: Uniwersytet Warszawski.

MALYSHEV L., 1993. Levels of the upper forest boundary in Northern Asia. Vegetatio, vol. 109, no. 2, pp. 175-186.

MalySheV L., Nimis P.L., 1997. Climatic dependence of the ecotone between alpine and forests orobiomes in southern Siberia. Flora, vol. 192, no. 2, pp. 109-120.

MAREK R., 1910. Waldgrenzstudien in den österreichischen Alpen. Gotha: J. Perthes.

Martazinova V., Ivanova O., Shandra O., 2011. Climate and treeline dynamics in the Ukrainian Carpathians Mts. Folia Oecologica, vol. 39, no. 1, pp. 65-71.
Michaelis W., 1997. Air pollution: Dimensions, trends and interactions with a forest ecosystem. Berlin: Springer.

Minal B., Savulescu I., Sandric I., Oprea R., 2006. Application de la détection des changements à l'étude de la dynamique de la végétation des monts de Bucegi (Carpates Méridionales, Roumanie). Télédétection, vol. 6, no. 3, pp. 215-231.

Mihai B., Savulescu I., Sandric I., 2007. Change detection analysis (1986-2002) of vegetation cover in Romania. A Study of alpine, subalpine, and forest landscapes in the lezer Mountains, Southern Carpathians. Mountain Research and Development, vol. 27, no. 3, pp. 250-258.

MORK E., 1968. Ökologiske undersökelser i Nord-Norge [in:] A. Sveli (ed.), Skogbruk i Nord-Norge: Streiftog gjennom historien, Trondheim Nord-Norges Skogmannsforbund, pp. 24-30.

Munteanu C., Kuemmerle T., Boltiziar M., Butsic V., Gimmi U., Halada L., Kaim D., Kiráay G., Konkoly-Gyuró E., Kozak J., Lieskovsky J., Mojses M., Müller D.,Ostafin K., Ostapowicz K., Shandra O., Stych P., Walker S., Radeloff V.C., 2014. Forest and agricultural land change in the Carpathian region - A meta-analysis of long-term patterns and drivers of change. Land Use Policy, 38, pp. 685-697.

Musielok Ł., Kacprzak A., Opyrchat J., 2013. Właściwości i pozycja systematyczna gleb rozwiniętych na ryolitach w Górach Kamiennych. Prace Geograficzne, 135. Kraków: Instytut Geografii i Gospodarki Przestrzennej Uniwersytetu Jagiellońskiego, pp. 21-39.

MuziKa R.M., Guyette R.P., ZielonKa T., LieBhold A.M., 2004. The influence of $\mathrm{O}^{3}, \mathrm{NO}^{2}$ and $\mathrm{SO}^{2}$ on growth of Picea abies and Fagus sylvatica in the Carpathian Mountains. Environmental Pollution, vol. 130, no. 1, pp. 65-71.

Myczkowski S., 1955a. Naturalne szpalery świerkowe nad górna granica lasu na stokach Matej Koszystej w Tatrach. Chrońmy Przyrodę Ojczysta, 2, pp. 22-27.

MyczKowski S., 1955b. O strefie górnej granicy lasu w Tatrach. Wierchy, 24, pp. 134-137.

MrczKowski S., 1956. Lawiny, a las tatrzański. Wierchy, 25, pp. 198-201

MrczKowski S., 1962. O górnych zasięgach drzew i lasu w Dolinie Rybiego Potoku, Wierchy, 31, pp. 188-191. 
MycZKowski S., 1964. Struktura i ekologia zespołu świerka Picetum tatricum u górnej granicy lasu w Tatrzańskim Parku Narodowym, w dolinach Stawów Gąsienicowych i Pańszczycy. Ochrona Przyrody, 30, pp. 51-105.

NiCIA P., 2009. Characteristics and problems of mountain and submontane fens protection [in:] A. Łachacz (ed.), Wetlands - their functions and protection, Contemporary Problems of Management and Environmental Protection, 7, Olsztyn: Department of Land Reclamation and Environmental Management. University of Warmia and Mazury in Olsztyn, pp. 125-138.

Norton D.A., Schonenberger W., 1984. The growth forms and ecology of nothofagus solandri at the alpine timberline, Craigieburn Range, New Zealand. Arctic, Antarctic and Alpine Research, vol. 16, no. 3, pp. 361-370.

OBIDOwICZ A., 1996. Polodowcowa historia szaty roślinnej [in:] Z. Mirek (ed.), Przyroda Tatrzańskiego Parku Narodowego, Kraków-Zakopane: Wydawnictwo Tatrzańskiego Parku Narodowego, pp. 229-236.

OBIDOWICZ A., 2003. The Holocen development of forest in the Pilsko Mt. Area (Beskid Żywiecki Range, South Poland). Fola Quaternaria, 74, pp. 7-15.

OBIDOwicz A., 2004. Holoceńska historia roślinności Babiej Góry [in:] B.W. Wołoszyn, A. Jaworski, J. Szwagrzyk (eds.), Babiogórski Park Narodowy, Monografia Przyrodnicza, Kraków: Wydawnictwo i Drukarnia Towarzystwa Słowaków w Polsce, pp. 423-428.

Osaci-Costache G., Ene M., 2010. The analysis of forest dynamics within the contact area between the Carpathians and Subcarpathians by using historical cartography approach and open source GIS software. Case study: The Llimpedea Catchment (Romania). Forum geografic. Studii și cercetări de geografie și protecția mediului, vol. 9, no. 9, pp. 115-124.

Paterek A., OlęDzki J.R., 2005. Zmiany w zasięgu pięter roślinnych w Tatrach w latach 1977-1999. Teledetekcja Środowiska, 36, pp. 106-118.

Paterson W.S.B., 1994. The physics of glacier. New York: Pergamon.

Paulsen J., Weber U.M. Körner Ch., 2000. Tree growth near treeline: Abrupt or gradual reduction with altitude. Arctic, Antarctic and Alpine Research, vol. 32, no. 1, pp. 14-20.
PięKó́-Mirkowa H., Mirek Z., 1996. Zbiorowiska roślinne [in:] Z. Mirek (ed.), Przyroda Tatrzańskiego Parku Narodowego, Kraków-Zakopane: Wydawnictwo Tatrzańskiego Parku Narodowego, pp. 234-273.

Plesník P., 1955. Vplyv pasenia na lesy Krivánskej Malej Fatry. Les, vol. 2, no. 1-2, pp. 29-37.

PLESNík P., 1956. Horná hranica lesa v Krivánskej Malej Fatre. Lesnícky Časopis, vol. 2, pp. 97-123.

PLESNík P., 1957. Vplyv vetra na tvar koruny a kmeňa smrekov v oblasti hornej hranice lesa v Krivánskej Malej Fatre. Geografický Časopis, Bratislava, vol. 9, no. 4, pp. 197-224.

PLESNÍK P., 1958. Erózia pôdy v oblasti hornej hranice lesa v Kriváňskej Malej Fatre [in:] D. Zachar (ed.), Vodná erózia na Slovensku, Bratislava: Slovenská akadémia vied, pp. 102-121.

Plesník P., 1966. Horná hranica lesa na Vel'kom Choči, Geografický Časopis, 18, pp. 56-76.

PLESNík P., 1967. Vplyv geomorfologických pomerov na hornú hranicu lesa vo Vysokých Tatrách. Geografický Časopis, 19, pp. 81-92.

PLESNík P., 1971. Horná hranica lesa vo Vysokých a Belanských Tatrách. Bratislava: Slovenská akadémia vied.

Plesník P., 1973. La Limite Supérieure de la Forêt dans les Hautes Tatras. Arctic, Antarctic and Alpine Research, vol. 5, pp. 3, pp. 37-44.

PLESNÍK P., 1978. Man's Influence on the Timberline in the West Carpathian Mountains, Czechoslovakia. Arctic, Antarctic and Alpine Research, vol. 10, no. 2, pp. 495-504.

PLESNík P., 2002. Niektoré nové aspekty diverzity biosféry. Geografický Časopis, vol. 54, no. 2, pp. 115-130.

PrICE L.W., 1981. Mountain and Man. Berkeley-Los Angeles-Paris: University of California Press.

RĄCZKOWSKA Z., 2007. Wspótczesna rzeźba peryglacjalna wysokich gór Europy. Prace Geograficzne, 212, Warszawa: Instytut Geografii i Przestrzennego Zagospodarowania PAN.

ReAD D.J., 1998. The mycorrhizal status of Pinus [in:] D.M. Richardson (ed.), Ecology and biogeography of Pinus. Cambridge: Cambridge University Press, pp. 324-340.

Read D.J., Perez-Moreno J., 2003. Mycorrhizas and nutrient cycling in ecosystems - a journey towards relevance? New Phytologist, vol. 157, no. 3, pp. 475-492. 
Richuing A., Solon J., 1996. Ekologia krajobrazu. Warszawa: Państwowe Wydawnictwo Naukowe.

RoB M., TAUT I., 2007. Considerations concerning the altitudinal limit of the beech forests from the Gutâi mountains. Bulletin of University of Agricultural Sciences and Veterinary Medicine Cluj-Napoca. Horticulture, vol. 64, no.1-2, pp. 261-265.

Rов M., 2008. Natural superior limit of the forest in the Gutâi mountains. Studia Universitatis Vasile Goldis Seria Stiintele Vietii (Life Sciences Series), 18, pp. 325-331.

Rossi S., Deslauriers A., Anfodillo T., Carraro V., 2007. Evidence of threshold temperatures for $x y$ logenesis in conifers at high altitudes. Oecologia, vol. 152, no. 1, pp. 1-12.

SAKAI A., LARCHER W., 1987. Frost survival of plants: Responses and adaptations to freezing stress. Ecological Studies, 62. Berlin- Heidelberg-New York: Springer.

SarmiEnTO F.O., 2002. Anthropogenic change in the landscapes of highland Ecuador. Geographical Review, vol. 92, no. 2, pp. 213-234.

SChrÖter C., 1926. Das Pflanzenleben der Alpen. Zürich: A. Raustein.

SeBEN V., 2005. Zhodnotenie protilavínového ochranného zalesñovania na hornej hranici lesa $\checkmark$ Nízkych Tatrách (TVP Velký Bok). Zprávy lesnického výzkumu, vol. 50, no. 2, Praha-Zbraslav nad Vltavou: Výzkumný ústav lesního hospodářství a myslivosti Jíloviště-Strnady, pp. 101-108.

Shandra O., Weisberg P., Martazinova V., 2013. Influences of climate and land use history on forest and timberline dynamics in the Carpathian Mountains during the twentieth century [in:] J. Kozak, K. Ostapowicz, A. Bytnerowicz, B. Wyżga (eds.), The Carpathians: Integrating nature and society towards sustainability, Environmental Science and Engineering. Berlin-Heidelberg: Springer-Verlag, pp. 209-223.

SHIYATOV S.G., 1966. Time of dispersion of Siberian larch seeds in north-western part of its areal space and role of that factor in mutual relation between forest and tundra. Problems of Physiology and Geobotany, 4, Sverdlovsk: Sverdlovsk Branch of the All-Union Botanical Society, pp. 109-113 [in Russian].

Sitko I., Troll M., 2008. Timberline changes in relation to summer farming in the Western Chornohora (Ukrainian Carpathians). Mountain
Research and Development, vol. 28, no. 3-4, pp. 263-271.

Slatyer R.O., Noble I.R., 1992. Dynamics of montane treelines [in:] A. Hansen, F. di Castri (eds.), Landscape boundaries: Consequences for biotic diversity and ecological flows, Ecological Studies, 92, pp. 346-359.

SoKOŁowski M., 1928. O górnej granicy lasu w Tatrach. Zakład Badania Drzew i Lasu, 1, Kraków: Zakłady Kórnickie.

SOMORA J., 1958. O rozšíreni niektorých lesných drevín v skupine Lomnického štítu. Martin: Vydavatel'stvo Osveta.

SOMORA J., 1969. Die theoretische Problematik der Waldgrenze. Sborník Prác o Tatranskom Národnom Parku, 11, pp. 139-176.

Sowell J.B., Koutnik D.L., LAnsing A.J., 1982. Cuticular transpiration of whitebark pine (Pinus albicaulis) within a Sierran Nevadan timberline ecotone, U.S.A. Arctic, Antarctic and Alpine Research, vol. 14, no. 2, pp. 97-103.

Staszic S., 1815. O ziemiorodztwie Karpatów i innych gór i równin Polski. Warszawa: Wydawnictwa Geologiczne.

SteVEnS G.C., Fox J.F., 1991. The causes of treeline. Annual Review of Ecology, Evolution, and Systematics, 22, pp. 177-191.

Stoffel M., Bollschweller M., Butler D.R., LuCKMAN B.H., (eds.), 2010. Tree rings and natural hazards: a state-of-art Dordrecht: Springer.

ŠVAJdA J., SOlÁr, J., JanIGA M., Buliak M., 2011. Dwarf Pine (Pinus mugo) and selected abiotic habitat conditions in the Western Tatra Mountains. Mountain Research and Development, vol. 3, no. 3, pp. 220-228

SvoBODA P., 1934. O horní hranici lesa. Československýles, 14, pp. 144-146, 153-157, 200-204.

SzWAgrzyK J., SzewCZYK J., Kaczor K., 1996. Relationship between stand structure and advanced forest regeneration in an old-growth stand of $B a-$ bia Gora National Park. Ekologia Polska, vol. 44, no. 1-2, pp. 137-152.

SzWagrzYK J., SzeWCZYK J., BodzIARCZYK J., 1997. Spatial variability of a natural stand in the Babia Gora National Park. Folia Forestalia Polonica. Series A .Forestry, vol. 39, pp. 61-78.

SzYMAŃSKI S., 2000. Ekologiczne podstawy hodowli lasu. Warszawa: Państwowe Wydawnictwo Rolnicze i Leśne. 
Środoń A., 1948. Górna granica lasu na Czarnohorze i w Górach Czywczyńskich. Rozprawy Wydziału Matematyczno-Przyrodniczego Polskiej Akademii Nauk, vol. 72, no. 7, pp. 513-606.

TANASE G., 2013. Evoluția limitei superioare a pădurii în masivul Giumalău în perioada 1855 -2006. Revista GEOCONCEPT, 1.

TIMONEY K.P., LAROI G.H., ZOLTAI S.C., Robinson A.L., 1992. The high subarcticforest of northwestern Canada: Position, width, and vegetation gradients in relation to climate. Arctic, vol. 45, no. 1, pp. 1-9.

TOlLner H., 1949. Der Einfluß großer Massenerhebung auf die Lufttemperatur und die Ursachen der Hebung der Vegetationsgrenzen in den inneren Ostalpen. Archiv für Meteorologie, Geophysik und Bioklimatologie. Serie B1, vol. 1, no. 3-4, pp. 347-372.

Török-Oance M., Voiculescu M., Ardelean M., Vuia F., TÖrÖK-OAnce R., 2006. Considérations sur les limites actuelles de l'étage alpin du massif de Făgăraș (Carpates Roumaines) en utilisant la Télédétection et les SIG. Télédétection, vol. 6, no. 3, pp. 205-213.

TÖRÖK-OAnCE R.,TÖRÖK-OAnCE M., 2012. Trends in land cover change in abandoned mountain pastures. A case study: Măgura Marga Massif (the Southern Carpathians). Forum geografic. Studii și cercetări de geografie și protecția mediului, vol. 11, no. 2, pp. 214-223.

TRANQUILLINI W., 1976. Water relations and alpine timberline [in:] O.L. Lange, L. Kappen, E-D. Schulze (eds.), Water and plant life, Ecological Studies, 19. Heidelberg-New York: Springer, pp. 473-491.

TRANQUILLINI W., 1979. Physiological ecology of the alpine timberline. Tree existence at high altitudes with special references to the European Alps. Ecological Studies, 31, Berlin: Springer.

TRANQUILLINI W., 1982. Frost drought and its ecological significance [in:] O.L. Lange, P.S. Nobel, C.B. Osmond, H. Ziegler (eds.), Encyclopaedia of plant physiology: New Series, vol. 12 B, Berlin-Heidelberg-New York: Springer, pp. 379-400.

TREML V., 2007. The effect of terrain morphology and geomorphic processes on the position and dynamics of the alpine timberline. A case study from the High Sudetes, Czech Republic [in:] A.S. Goudie, J. Kalvoda (eds.) Geomorphological variations, Prague: P3K, pp. 298-312.

Treml V., Jankovska V., Petr L., 2008. Holocene dynamics of the alpine timberline in the High Sudetes. Biologia, vol. 63, no. 1, pp. 73-80.
TROLL C., 1972. Geoecology and world-wide differentiation of high-mountain ecosystems [in:] C. Troll (ed.), Geoecology of the High-Mountain Regions of Euroasia. Wiesbaden: Steiner, pp. 264-275.

Troll C., 1973a. The upper timberline in different climatic zones. Arctic, Antarctic and Alpine Research, vol. 5, no. 3, pp. A3-A18.

TroLl C., 1973b. High mountain belts between the polar caps and the equator: Their definition and lower limit. Arctic, Antarctic and Alpine Research, vol. 5, no. 3, pp. A19-A27.

TROLL C., 1988. Comparative geography of the high mountains of the world in the view of landscape ecology [in:] N.J.R. Alan, G.W. Knap, C. Stadel (eds.), Human impact on mountains. Totowa: Rowman \& Littlefield, pp. 36-56.

TuČEK J., ŠKVARENINA J., VorČÁKJ., 2004. Uplatnenie GIS pri štúdiu imisnej zátaže horských ekosystémov Oravských Beskýd-Babej Hory. Bioklimatologické pracovné dni, http://fzki.uniag.sk/web/ bpd2004/content/01Plenarne_zasadnutie/ Tucek.pdf [5 March 2015].

TURNER H., 1961. Standortsuntersuchungen in der subalpinen Stufe: Die Niederschlags- und Schneeverhältnisse. Mitteilungen der Forstlichen Bundesversuchsanstalt Mariabrunn, vol. 59, pp. 265-315.

TURNER H., 1993. Alpine microclimates: Typology and examples [in:] T. Anfodillo, C. Urbinati (eds.), Ecologia delle foreste di alti quota, Corso di cultura in ecologia, 30, University of Padova, pp. 27-34.

TURNeR R.K. (ed.), 1988. Sustainable environmental menagament: Principles and practices. Boulder, Colorado: Westwiev Press.

Unsworth M.H., Fowler D., (eds.) 1988. Acid deposition processes at high altitudes. Dortrecht: Reidel.

Van der KnaAp W.O., van Leeuwen J.F., FankHauser A., Ammann B., 2000. Palynostratigraphy of the last centuries in Switzerland based on 23 lake and mire deposits: Chronostratigraphic pollen markers, regional patterns, and local histories. Review of Palaeobotany and Palynology, vol. 108, no. 1, pp. 85-142.

Van Westen C.J., Getahun F.L., 2003. Analyzing the evolution of the Tessina landslide using aerial photographs and digital elevation models. Geomorphology, vol. 54, no. 1, pp. 77-89.

VINCENT G., 1933. Topografie lesu v Československé Republice: Vysoké Tatry. Sbornik Vyzkumnych Ustavů Zemědělskych, 113, Praha. 
VorČák J., Merganič J., Saniga M., 2006a. Structural diversity change and regeneration processes of the Norway spruce natural forest in Babia Hora NNR in relation to altitude. Journal of Forest Science, vol. 52, no. 9, pp. 399-409.

VorČ́́́ J., MerganiČ J., Merganičova K., 2006b. Strukturalna diverzita smrekoveho prorodneho lesa v supramontannom stupni NPR Babia Hora. Beskydy, 19, pp. 143-148.

VORČÁK J., JANKOVIC J., 2009. Autovegetatívna obnova smreka na hornej hranici supramontánneho stupňa a $v$ subalpínskom stupni Babej Hory a Pilska v Oravských Beskydách. Lesnícky Časopis, vol. 55, no. 1, pp. 29-46.

Walas J., 1933. Roślinność Babiej Góry. Warszawa: Państwowa Rada Ochrony Przyrody.

Walter H., Medina E., 1969. Die Bodentemperatur als ausschlaggebender Faktor für die Gliederung der subalpinen und alpinen Stufe in den Anden Venezuelas (Vorläufige Mitteilung). Berichte der Deutschen Botanischen Gesellschaft, vol. 82, no. 3-4, pp. 275-281.

WARDLE P., 1971. An explanation for alpine timberline. New Zeaand Journal of Botany, vol. 9, no. 3, pp. 371-402.

Wardle P., 1974. Alpine timberlines [in:] J.D. Ives, R. Barry (eds.), Arctic and Alpine Environments, London: Methuen Publishing, pp. 371-402.

Weisberg P.J., Shandra O., Becker M.E., 2013. Landscape influences on recent timberline shifts in the Carpathian Mountains: Abiotic influences modulate effects of land-use change. Arctic, Antarctic, and Alpine Research, vol. 45, no. 3, pp. 404-414.

WiCK L., TINneR W., 1997. Vegetation changes and timberline fluctuations in the Central Alps as a indicators of Holocene climatic oscillations. Arctic, Antarctic and Alpine Research, vol. 29, no. 4, pp. 445-458.

Wick L., van LeEuWenl J.F.N., van der KNAAP W.O., LOTTER A.F., 2003. Holocene vegetation development in the catchment of Sägistalsee $1935 \mathrm{~m}$ asl), a small lake in the Swiss Alps. Journal of Paleolimnology, 30, pp. 261-272.

Wieser G., TAusz M. (eds.), 2007. Trees at their upper limit: Treelife limitation at the alpine timberline. Dordrecht: Springer.
WilczYŃSkI S., GotĄ J., 2001. Sygnat klimatyczny w słojach drewna buka zwyczajnego [Fagus sylvatica L.] z Beskidu Wyspowego. Sylwan, vol. 145, no. 10, pp. 61-72.

WiLczYŃSKI S., 2004. Specyficzność regionów górskich [in:] A. Zielski, M. Krapiec (eds.), Dendrochronologia, Warszawa: Państwowe Wydawnictwo Naukowe, pp. 268-270.

WóYcıcki Z., 1930. Roślinność pasma Czarnohory. Krajobrazy Roślinne Polski, 17, Warszawa: Wydawnictwo Kasy Imienia Mianowskiego.

WWF, 2001. The status of the Carpathians: A report developed as a part of the Carpathian Ecoregion Initiative. World Wide Fund for Nature, http:// www.carpates.org/docs/publications/status.pdf. [5 March 2015].

Zabielski B., Magnuski K., WażYŃSKI B., ŻÓtCIAK E., 1969. Gospodarka leśna na terenie Babiogórskiego Parku Narodowego w latach 1844-1971. Prace Komisji Nauk Rolniczych i Leśnych, 28, pp. 427-470.

Zapatowicz H., 1879. Roślinność Babiej Góry pod względem geograficzno-botanicznym. Sprawozdanie Komisyi Fizjograficznej. Materiały do fizjografii Galicji, 14, pp. 79-250.

Zapałowicz H., 1889. Roślinna szata gór Pokucko-Marmaroskich. Sprawozdanie Komisyi Fizjograficznej, 24, Kraków: Uniwersytet Jagielloński.

ZARZYCKI K., 1963. Lasy Bieszczadów Zachodnich. Acta Agraria et Silvestra, 3, Kraków: Polska Akademia Nauk.

ZIENTARSKI J., 1976. Wpływ wzniesienia nad poziomem morza na zagęszczenie i ukształtowanie górnoreglowych borów świerkowych w Babiogórskim Parku Narodowym. Prace Komisji Nauk Rolniczych i Leśnych, 42, pp. 137-149.

ZIENTARSKI J., 1985. Wpływ wzniesienia oraz wielkości masywu górskiego na kształtowanie się górnej granicy lasu w Polsce. Poznań: Akademia Rolnicza [PhD thesis].

ZieNTARSKI J., 1989. Górna granica lasu w Babiogórskim Parku Narodowym [in:] S. Korpel (ed.), Stav, vyvoj, produkčne schopnosti a funkce vyuzivanie lesov v oblasti Babej Hory a Pilska, Zvolen: Technická univerzita. Vysoká škola lesnícka a drevárska, pp. 122-148.
(C) Barbara Czajka • Adam Łajczak • Ryszard J. Kaczka • Paweł Nicia

(C) Geographia Polonica

(C) Institute of Geography and Spatial Organization

Polish Academy of Sciences - Warsaw • 2015
Article first received • December 2014 Article accepted $\bullet$ March 2015 